\title{
Filtering Capability of Porous Pavements ${ }^{\dagger}$
}

\section{Liseane Padilha Thives *, Enedir Ghisi, Douglas G. Brecht and Dario M. Pires}

Department of Civil Engineering, Federal University of Santa Catarina, Florianópolis-SC 88037-000, Brazil; enedir@labeee.ufsc.br (E.G.); douglasghbr@hotmail.com (D.G.B.); dariomenegasso@gmail.com (D.M.P.)

* Correspondence: liseane.thives@ufsc.br or liseanethives@gmail.com; Tel.: +55-48-3721-2114

+ Presented at the 2nd International Electronic Conference on Water Sciences, 16-30 November 2017; Available online: http://sciforum.net/conference/ecws-2.

Published: 16 November 2017

\begin{abstract}
The objective of this study is to assess the filtering capability of porous pavement models and the quality of rainwater and stormwater filtered by such models. Three slabs of porous asphalt mixtures and two systems composed of porous layers that resulted in porous pavement structures were produced. Data were collected in two phases: using rainwater directly from the sky and then using stormwater collected from a street. The models with different layers were assembled in acrylic boxes and rainwater was stored in the boxes in each rainfall event. Parameters such as $\mathrm{pH}$, dissolved oxygen, ammonia, phosphorus, nitrite, aluminium, chromium, copper, zinc and iron were measured. The infiltration capacity of the models varied from $83.4 \%$ to $83.7 \%$. For both rainwater and stormwater quality analyses, there was an increase in the concentration of the following parameters: phosphorus, iron, aluminium, zinc, nitrite, chromium, cooper and $\mathrm{pH}$; there was no significant variation in the concentration of dissolved oxygen; and there was a decrease in ammonia in one of the models. However, the concentrations of only phosphorus and aluminium exceeded the limits established by the Brazilian National Environmental Council and National Water Agency for the use of non-potable water. The models were capable of filtering rainwater and stormwater, and reducing the concentration of ammonia. It can be concluded that it is possible to collect stormwater from asphalt porous surfaces and porous pavements. Porous pavements are able to filter out certain pollutants from stormwater and rainwater, and were shown to be an alternative to harvest rainwater for non-potable uses and to recharge the water table.
\end{abstract}

Keywords: porous pavement; filtering; rainwater

\section{Introduction}

The urbanization process and the disorganized occupation of urban centres to supply the needs of human beings promoted the transformation of the environment, which resulted in modifications and interferences in ecosystems [1]. The development of the road network combined with the growth of cities has led to impervious surfaces. As a result, the frequency and intensity of urban flood events mainly when drainage systems are unable to completely remove urban stormwater produced during intense rainfall have been increasing [2-4]. This scenario has led to the development of alternative techniques to increase drainage capability of surfaces, such as the use of porous pavements [3,5-7].

The role assigned to porous pavements consists of reducing pollution and runoff, and increasing stormwater infiltration. Porous pavements are specifically designed to promote the infiltration of stormwater through the paving and base courses where it is filtered through the layers $[1,4,6-8]$. This particular pavement may also result in a reduction in the amount of pollutants entering the groundwater by filtering the stormwater [5,9]. Porous pavements are more sustainable alternatives to traditional impervious asphalt and concrete pavements. Interconnected void spaces 
in the pavement allow for water to infiltrate into a subsurface storage zone during rainfall events $[10,11]$.

Stormwater is a water resource alternative that can bring benefits to urbanized communities. In addition, runoff from urban impervious surfaces often carries contaminants, sediments, and nutrients from the surface upon which it falls or flows that can degrade stream quality. However, the wide range of stormwater pollutants may present significant health risks [3,12].

Kumar et al., (2015) [13] measured the infiltration capability in three porous parking sections using different pavements during four years. Porous concrete pavers, porous concrete and porous asphalt were the pavements tested. It was observed that the infiltration rates decreased significantly due to clogging of pores by the deposition of particles, mainly during the last two years. The porous concrete obtained the best performance while the porous asphalt was the worst. However, all porous pavements in parking lots have a great ecological importance due to their ability to infiltrate rainwater quickly, which reduces runoff in the catchment area and avoids floods.

The general principle of porous pavement is to collect, treat and/or infiltrate freely any surface runoff to support groundwater recharge. These pavements provide a reduction of runoff volumes and discharge rates from paved surfaces $[7,14,15]$ which can potentially minimize the risk of flooding. Porous pavements also allow for considerable water quality improvements by treating and trapping stormwater pollutants $[14,16]$.

Drake et al., (2014) [17] examined the water quality performance of three porous pavement systems over spring, summer and fall in Ontario, Canada. The study showed that the use of porous pavements can mitigate the impact of urbanization on receiving surface water systems through quantity control and stormwater treatment.

The objective of this study is to assess the filtering capability of porous pavement models and the quality of rainwater and stormwater filtered by such models.

\section{Background}

\subsection{Porous Pavements Structures}

The porous pavements comprise a dual function, that is, as a stormwater management practice and to support traffic loads. These pavements can be composed of surface porous asphalt mixtures (open graded) over a permeable layer system (base and sub-base with course aggregate intercalated by a filter fabric) and the existing soil or subgrade material [18]. Porous asphalt mixtures have higher air voids (18 to $22 \%$ ). High-quality aggregates are needed to provide good aggregate interlock and long-term frictional properties [19]. In New Zealand, these mixtures are specified with air voids varying from $20 \%$ to $30 \%$ [20].

The high air voids lead to interconnected permeable voids, which create permeability in the pavement. Stormwater infiltrates through the pores and can be fast removed from the surface. This generates a permeable interconnected void structure that can work as a filter for stormwater. The base course layer typically consists of an open graded base comprised of unbound granular materials. Base course or stone recharge bed consists of clean single-size aggregates with about $40 \%$ void content. A stabilizing course (chokers course), which contains single-size aggregates smaller than recharge bed, is also used [21].

\subsection{Pollutants}

Stormwater contains pollutants and nutrients that can threaten soils, groundwater, rivers and seas. Rainwater may contain very high concentrations of sulphate, chloride, ammonia and phosphate. Several categories of pollutants have been identified as important constituents including: suspended solids, oxygen demand, nutrients, heavy metals, organic compounds and petroleum products. Table 1 shows the concentrations of pollutants found in the stormwater in different places [22-24]. 
Table 1. Pollutants measured in stormwater.

\begin{tabular}{|c|c|c|c|}
\hline Pollutant/Parameter & [22] & [23] & [24] \\
\hline $\mathrm{pH}$ & $3.90-7.50$ & $\mathrm{n} / \mathrm{a}^{(1)}$ & $6.00-8.30$ \\
\hline Total phosphorus ( $\left.\mathrm{P}_{\mathrm{tot}}\right)$ & $0.01-0.19$ & $\mathrm{n} / \mathrm{a}^{(1)}$ & 0.23 \\
\hline Ammonia $\left(\mathrm{NH}_{4}\right)$ & $0.10-2.00$ & $\mathrm{n} / \mathrm{a}^{(1)}$ & $\mathrm{n} / \mathrm{a}^{(1)}$ \\
\hline $\mathrm{NO}_{3}$ & $0.10-7.40$ & $\mathrm{n} / \mathrm{a}^{(1)}$ & $\mathrm{n} / \mathrm{a}^{(1)}$ \\
\hline Cadmium (Cd) & $0.10-3.90$ & $10.00-150.00$ & $<0.01$ \\
\hline Zinc (Zn) & $5.00-235.00$ & 40.00 & 0.52 \\
\hline Copper $(\mathrm{Cu})$ & $1.00-355.00$ & $3.00-370.00$ & $<0.10$ \\
\hline Lead $(\mathrm{Pb})$ & $2.00-76.00$ & $11.00-84.00$ & $<0.20$ \\
\hline Nickel (Ni) & $1.00-14.00$ & $5.00-33.00$ & $<0.03$ \\
\hline Chromium (Cr) & $2.00-8.00$ & $\mathrm{n} / \mathrm{a}^{(1)}$ & 0.05 \\
\hline Iron $(\mathrm{Fe})$ & $\mathrm{n} / \mathrm{a}^{(1)}$ & $21.00-633.00$ & $\mathrm{n} / \mathrm{a}^{(1)}$ \\
\hline
\end{tabular}

Highway stormwater contains a variety of pollutants which, if left untreated, can impair water quality and pose a risk to aquatic organisms [22,25]. Table 2 shows the concentrations of pollutants from highway runoff in different places in Europe [22], in western Washington State [25] and in Texas, in the United States [1,26].

Table 2. Pollutants measured in stormwater.

\begin{tabular}{|c|c|c|c|c|}
\hline Pollutant/Parameter & [1] & [22] & [25] & [26] \\
\hline $\mathrm{pH}$ & $\mathrm{n} / \mathrm{a}^{(1)}$ & $6.4-7.9$ & $5.8-6.8$ & $6.51-7.16$ \\
\hline Total phosphorus ( $\left.\mathrm{P}_{\text {tot }}\right)$ & $0.04-0.14$ & $0.23-0.34$ & $0.03-0.57$ & $0.10-0.42$ \\
\hline Ammonia $\left(\mathrm{NH}_{4}\right)$ & $\mathrm{n} / \mathrm{a}^{(1)}$ & $0.5-2.3$ & $1.0-2.7$ & $\mathrm{n} / \mathrm{a}^{(1)}$ \\
\hline $\mathrm{NO}_{3}$ & $\mathrm{n} / \mathrm{a}^{(1)}$ & $0.1-16.0$ & $\mathrm{n} / \mathrm{a}^{(1)}$ & $0.28-1.25$ \\
\hline Cadmium $(\mathrm{Cd})$ & $\mathrm{n} / \mathrm{a}^{(1)}$ & $0.3-13.0$ & $0.9-2.8$ & $\mathrm{n} / \mathrm{a}^{(1)}$ \\
\hline Zinc $(\mathrm{Zn})$ & $22.0-610$ & $120.0-2000.0$ & $26.0-394.0$ & $50.0-237.0$ \\
\hline Copper $(\mathrm{Cu})$ & $11.0-180.0$ & $97.0-104.0$ & $4.6-72.0$ & $7.0-38.0$ \\
\hline Lead $(\mathrm{Pb})$ & $1.0-76.0$ & $11.0-525.0$ & $24-1065.0$ & $7.0-99.0$ \\
\hline Nickel (Ni) & $\mathrm{n} / \mathrm{a}^{(1)}$ & $4.0-70.0$ & $8.6-12.9$ & $\mathrm{n} / \mathrm{a}^{(1)}$ \\
\hline Chromium (Cr) & $\mathrm{n} / \mathrm{a}^{(1)}$ & $6.0-50.0$ & $\mathrm{n} / \mathrm{a}^{(1)}$ & $\mathrm{n} / \mathrm{a}^{(1)}$ \\
\hline Iron $(\mathrm{Fe})$ & $\mathrm{n} / \mathrm{a}^{(1)}$ & $\mathrm{n} / \mathrm{a}^{(1)}$ & $2429.0-10,300.0^{(2)}$ & $361.0-2606.0$ \\
\hline
\end{tabular}

Yuen et al., (2012) [27], in research conducted in Singapore, evaluated the amount of sediment stored on the surface of industrial and residential roads. Concentrations of cobalt, chromium, iron and nickel in industrial area roads were higher than those in residential roads. But scandium was higher in residential roads. In contrast, significant enrichment signals were observed for copper, lead, antimony and zinc in both industrial and residential areas.

In an experiment in Texas (United States), the researchers concluded that stormwater quality from road runoff is generally similar to that reported for urban runoff and does not contain higher concentrations of toxic metals or oil and grease [25]. In Maryland and Virginia (United States) a porous pavement was monitored in order to estimate the capability of porous asphalt to remove pollutants. The studies showed that $82 \%$ to $95 \%$ of sediment is removed as well as $65 \%$ of total phosphorus, and $80 \%$ to $85 \%$ of total nitrogen [28].

The storage capacity and efficiency of the system is dependent on the degree of clogging within the porous system [29]. In France, hydraulic conductivity and the level of pollutants in stormwater runoff from porous and conventional (impermeable) pavements were also studied. Concerning the 
quality of water, suspended solid sediments were detected. These particles were mostly fine sand. In the chemical analysis, the following pollutants were found: cadmium, copper, zinc and lead. A reduction in the percentage (greater than $70 \%$ for all metals) of suspended solids in which the conventional pavement was replaced by porous one was observed [30].

\subsection{Water Quality Released into the Environment}

Stormwater quality is associated to aquatic toxicity, which is influenced by several inorganic and organic pollutants. High concentrations of some parameters $(\mathrm{Fe}, \mathrm{Al}, \mathrm{Zn}, \mathrm{Cu}, \mathrm{Cd}, \mathrm{Pb})$ in the stormwater are caused by atmospheric transport of human activities (industrial activity, coal combustion and car exhaust) [26].

In Brazil, the National Water Agency (ANA - Agência Nacional de Águas, in Portuguese) [31] establishes limits for the use of non-potable water for specific purposes such as cleaning outdoor areas, toilet flushing, car wash, among others. For reuse water Class No. 1, ANA [31]. establishes limits for the following prevailing uses: toilet flushing, sidewalks cleaning, ornamental purpose and washing vehicles (Table 3).

Table 3. Water quality limits for non-potable purposes.

\begin{tabular}{ccc}
\hline Pollutant/Parameter & [31] & [32] \\
\hline $\mathrm{pH}$ & 6.0 to 9.0 & - \\
Total phosphorus (Pt) max. & $0.1 \mathrm{mg} / \mathrm{L}$ & - \\
Dissolved copper (Cu) max. & - & $1.0 \mathrm{mg} / \mathrm{L}$ \\
Total chromium (Cr) max. & - & $1.0 \mathrm{mg} / \mathrm{L}$ \\
Dissolved iron (Fe) max. & - & $15.0 \mathrm{mg} / \mathrm{L}$ \\
Total zinc (Zn) max. & - & $5.0 \mathrm{mg} / \mathrm{L}$ \\
Nitrite (Ni) max. & $1.0 \mathrm{mg} / \mathrm{L}$ & - \\
Ammonia max. & $20.0 \mathrm{mg} / \mathrm{L}$ & - \\
Odour and aspect & not unpleasant & - \\
Fecal coliforms & not detectable & - \\
\hline
\end{tabular}

The National Environmental Council, Resolution No. 430, provides the classification of water bodies, environmental guidelines and establishes the effluent discharge conditions [32]. Effluent discharge pattern from some pollution sources must follow the quality parameters and maximum values in accordance with Table 3. Furthermore, for dissolved oxygen and dissolved aluminium, there are no established limits for non-potable water. Therefore, the limits used for comparison are those established for potable water in accordance to Resolution No. 357 as not lower than $6.0 \mathrm{mg} / \mathrm{L}$ for dissolved oxygen and $0.10 \mathrm{mg} / \mathrm{L}$ for dissolved aluminium [33].

\section{Methodology}

This study evaluated the efficiency of porous pavements in relation to their draining and filtering capacity of rainfall and stormwater. For this, three porous asphalt mixtures slabs were produced, and two pavement systems with permeable layers were tested.

Data collection was performed in two stages. First, using rainfall directly from the sky, and then using stormwater collected from a street. In order to evaluate the draining properties, the slabs and the pavement systems were assembled in acrylic boxes and were exposed to rainfall events and then to stormwater. Also, the quality of water collected after passing through the slabs and models was analysed. An empty box with the same dimensions was used as a control. Figure 1 shows the scheme of the methodology. 


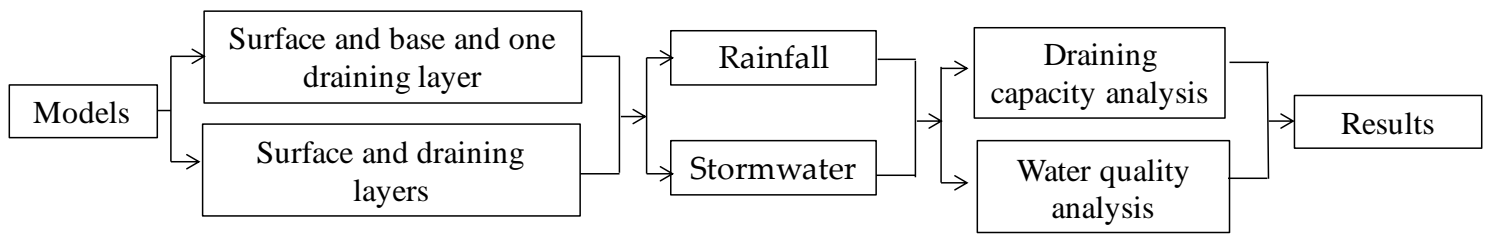

Figure 1. Scheme of the methodology used in this study.

\subsection{Materials}

The porous asphalt mixtures slabs were composed of coarse aggregate, fine aggregate, and rubber modified binder. The other layers that compose the models were crushed aggregates and sand, those were wrapped in geotextile blankets.

\subsubsection{Porous Asphalt Mixtures}

For the production of asphalt mixtures, granitic aggregates in the following maximum diameters: crushed coarse 3/4" and 3/8", and crushed fine (maximum nominal size of $4.75 \mathrm{~mm}$ ) were used. The specific gravities and the absorption of the aggregates can be seen in the Appendix (Table A1). The tests were performed in accordance with Brazilian standards DNER-ME 081/98 and DNER-ME 084/95 [34].The mixtures were prepared using the terminal blending asphalt rubber, with $15 \%$ of incorporated rubber, whose characterization is shown in Table A2 in the Appendix.

Porous asphalt mixtures were produced using open gradations, in which three specifications were used. The asphalt content and volumetric parameters of the mixtures were evaluated according to SUPERPAVE ${ }^{\circledR}$ method using a gyratory compactor (ASTM, 2002) [35].

The gradation curves (See Appendix, Table A3) were defined by following specifications and design from: (i) CALTRANS-California Department of Transportation (CT 368) Open Graded Friction Course (OGFC) 1/2-inch [36], designed with 23\% of voids content and 3.5\% of binder content; (ii) CPA - DNER-ES 386/99 [34] Porous Friction Course, grade IV (CPA - Camada Porosa de Atrito, in Portuguese), with $29 \%$ of voids content and $3.5 \%$ of binder content; (iii) PMQ-PMSP/SP-ESP10/92 [37] Porous Asphalt Mixture, grade I (PMQ-Pré-Misturado a Quente, in Portuguese) using $25 \%$ of voids content and $4.5 \%$ of binder content.

After being designed, the mixtures were produced and compacted in slabs using a French compactor (Institut Français des Sciences et Technologies des Transports, in French) to achieve the apparent density of the mixtures defined in the design. The CPA and Caltrans slabs were moulded with $7.0 \mathrm{~cm}$ thickness and the PMQ with $5.0 \mathrm{~cm}$. This was due to the fact that, in the pavement structures, PMQ mixture is generally used as a binder layer and the others as a surface. The thicknesses adopted aimed at improving the mechanical strength of the structure.

The thickness of surface layers of porous pavements in Brazil range from 4.0 to $8.0 \mathrm{~cm}$. In this study, we chose a surface layer thickness equal to $7.0 \mathrm{~cm}$ and asphalt base layer (PMQ) thickness equal to $5.0 \mathrm{~cm}$. The use of asphalt rubber as a binder was due to Brazilian regulations that require that porous asphalt mixtures should be made using polymeric asphalts; this is necessary because conventional asphalt does not meet the requirements of durability for mixtures with high voids.

\subsubsection{Porous Layers}

Different structures were adopted in the models. The porous layers followed the New Hampshire Stormwater Center [38] and Brazilian specifications [34] (See Appendix, Table A4).

\subsubsection{Equipment for Assembly of Models}

The models were assembled in acrylic boxes with $8.0 \mathrm{~mm}$ wall thickness. The boxes have the following dimensions: $50.0 \times 18.0 \mathrm{~cm}$ internal base and $53.0 \mathrm{~cm}$ height. Acrylic filets were installed to support the compacted porous mixtures and ensure a cross slope of $2.5 \%$ to represent the road cross slopes, which serves to drain runoff from the road surface. 
The metal legs system is height adjustable to provide the different heights of the different models. A hose was fixed internally to allow for removing the rainwater from the boxes after each rainfall event. Figure 2 shows the system with adjustable legs, fixed base and coupled metal grid and hose. An empty box was used as the control to measure the height of the rainwater stored in each rainfall event.

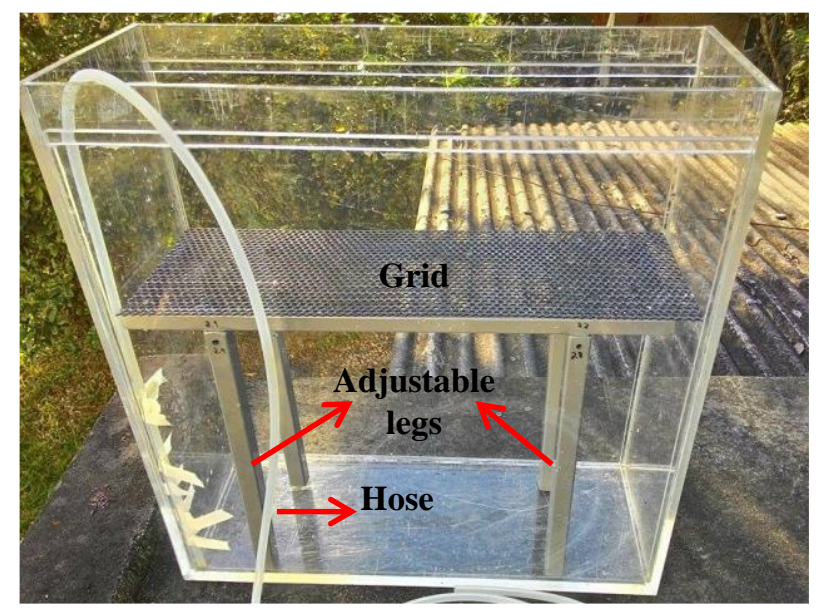

Figure 2. Box system used to place the models.

\subsubsection{Models}

Two models of porous pavements structures were evaluated (A and B). The components layers of each model are shown in Figure 3 and the specifications are shown in the Appendix (Table A5).

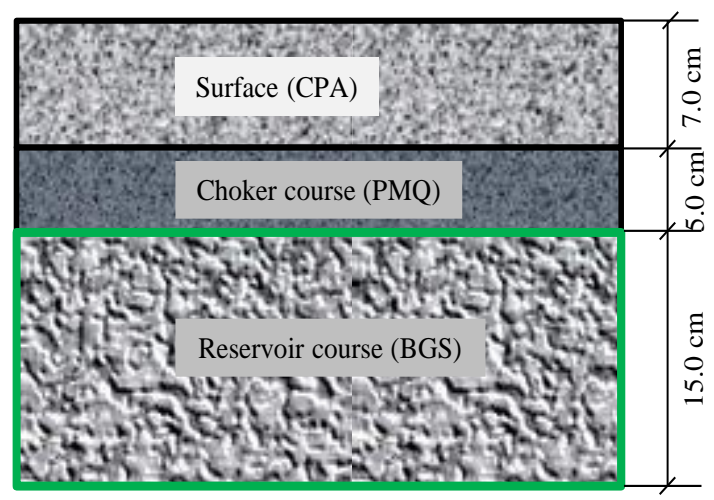

- Geotextile

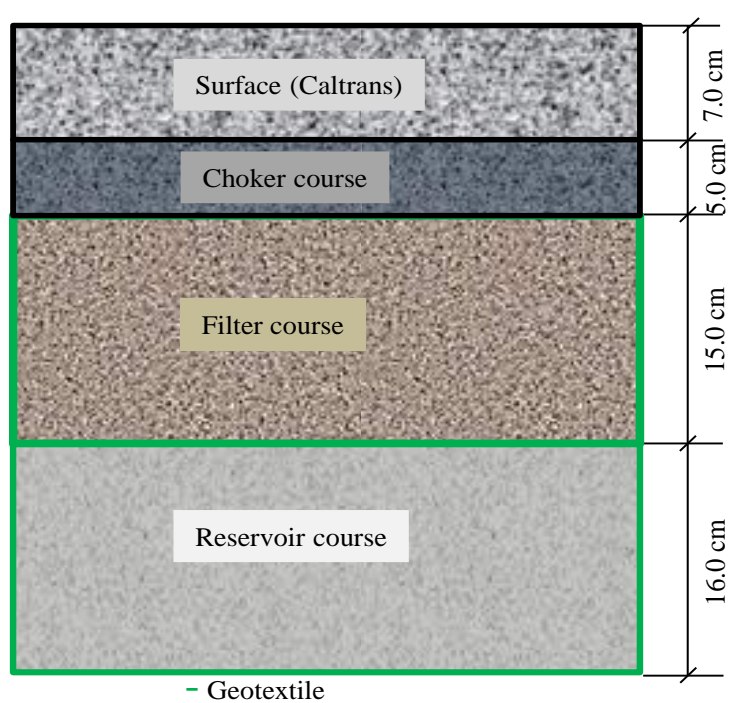

- Geotextile

Figure 3. Details of the layers for the two models.

In both models a porous asphalt surface layer and the underlying layers called porous layers (base, filter, and reservoir) were used. The porous layers, except the PMQ layer (choker course in Model A), were wrapped in geotextile mat. The geotextile was used to assembly the models for two main reasons. First, to confine the layers composed of materials without cohesion (aggregates) inside the box, and second as an attempt to simulate the structure of a pavement in the field. Also, some studies have shown that the filtering capacity of porous pavement increases when geotextile is used $[39,40]$. Figure 4 shows the models assembled in the boxes. 


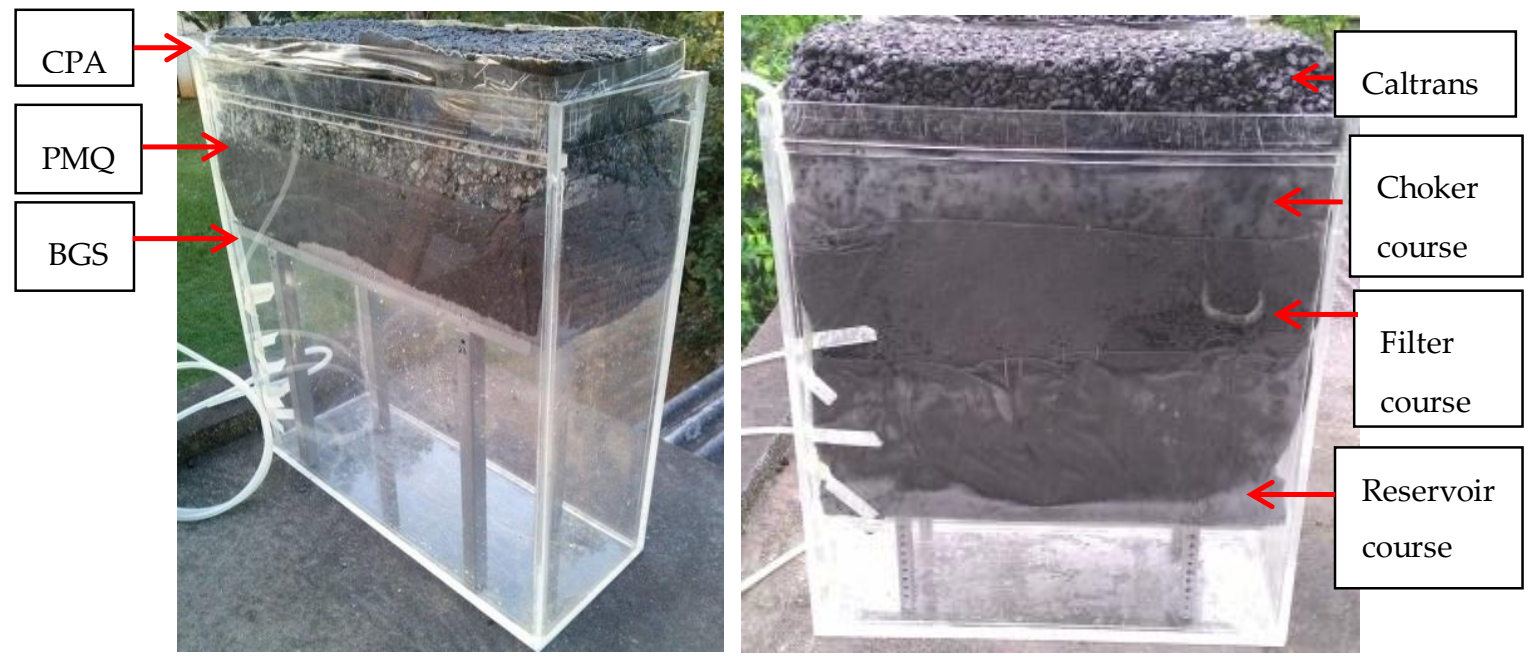

Figure 4. Models assembled in the boxes.

\subsection{Method}

\subsubsection{Quantity Analysis}

In order to assess the efficiency of the slabs and models in relation to runoff and infiltration after rainfall events, the amount of rainwater collected in the control box was compared to that passed through the models. The infiltration capacity was obtained by using Equation (1). It was assessed for the three asphalt slabs and the two models.

$$
\mathrm{E}=\left(\frac{\mathrm{h}_{1}}{\mathrm{~h}_{2}}\right) \times 100
$$

where: $\mathrm{E}$ is the infiltration capacity $(\%)$; $\mathrm{h}_{1}$ is the height of rainwater stored in the box that contain the model (mm); $h_{2}$ is the height of rainwater stored in the control box ( $\mathrm{mm}$ ).

Stormwater collected from the road was stored in bottles and then discharged on the models. Based on the area of the asphalt slabs and the average rainfall intensity in the region of Florianópolis, the duration of discharge for the amount of stormwater collected each time was estimated. Thus, the calculation was performed for each sample.

\subsubsection{Quality Analysis}

The quality analysis was performed in two stages: (i) using rainwater collected directly from the sky; (ii) using stormwater collected from a street. This analysis was performed for the two models only.

The parameters selected for water analysis were the following: ammonia, phosphorus, nitrite, dissolved oxygen, $\mathrm{pH}$, aluminium, copper, chromium, iron, and zinc. The analyses of these parameters were performed according to the guidelines of the chemical reagents supplier (Alfakit). A photocolorimeter AT 10P was used, except for the analyses that need colorimetric comparison. This instrument has a resolution of $0.01 \mathrm{mg} / \mathrm{L}$, margin of error of $3 \%$ and relative precision of $2 \%$.

The total fecal coliforms, was analysed according to Brazilian standard CETESB L5.202/1993 [41], using the multiple tubes method [42].

Stormwater was collected from the gutters of a local road with a low volume of heavy traffic and high volume of cars. During each rainfall event, stormwater was collected $15 \mathrm{~min}$ from the beginning of the event and stored in PVC (Polyvinyl Chloride) bottles; a control sample was also selected.

We chose to collect the samples of stormwater up to $15 \mathrm{~min}$ from the beginning of the rainfall event so that the stormwater would contain the maximum of contaminating materials deposited on the road surface. After that, the materials would be carried away by the runoff, and therefore fewer amounts of pollutants would be detected. And then the analyses were performed up to $30 \mathrm{~min}$ from 
the beginning of the rainfall event; this was possible as the laboratory where the analyses were performed is located near the place where the samples were collected.

\section{Results and Discussion}

\subsection{Quantity Analysis}

Figure 5 shows the relationship between rainfall height in the control box and rainfall infiltrated through the slabs, as well as the average infiltration capacity. It is observed that the slab with higher air voids (CPA) had the highest infiltration capacity $(87.3 \%)$. All porous mixtures had good infiltration capacity, above $67 \%$. Models A and B were also exposed to rainfall events. Their infiltration capacities are shown in Figure 6.

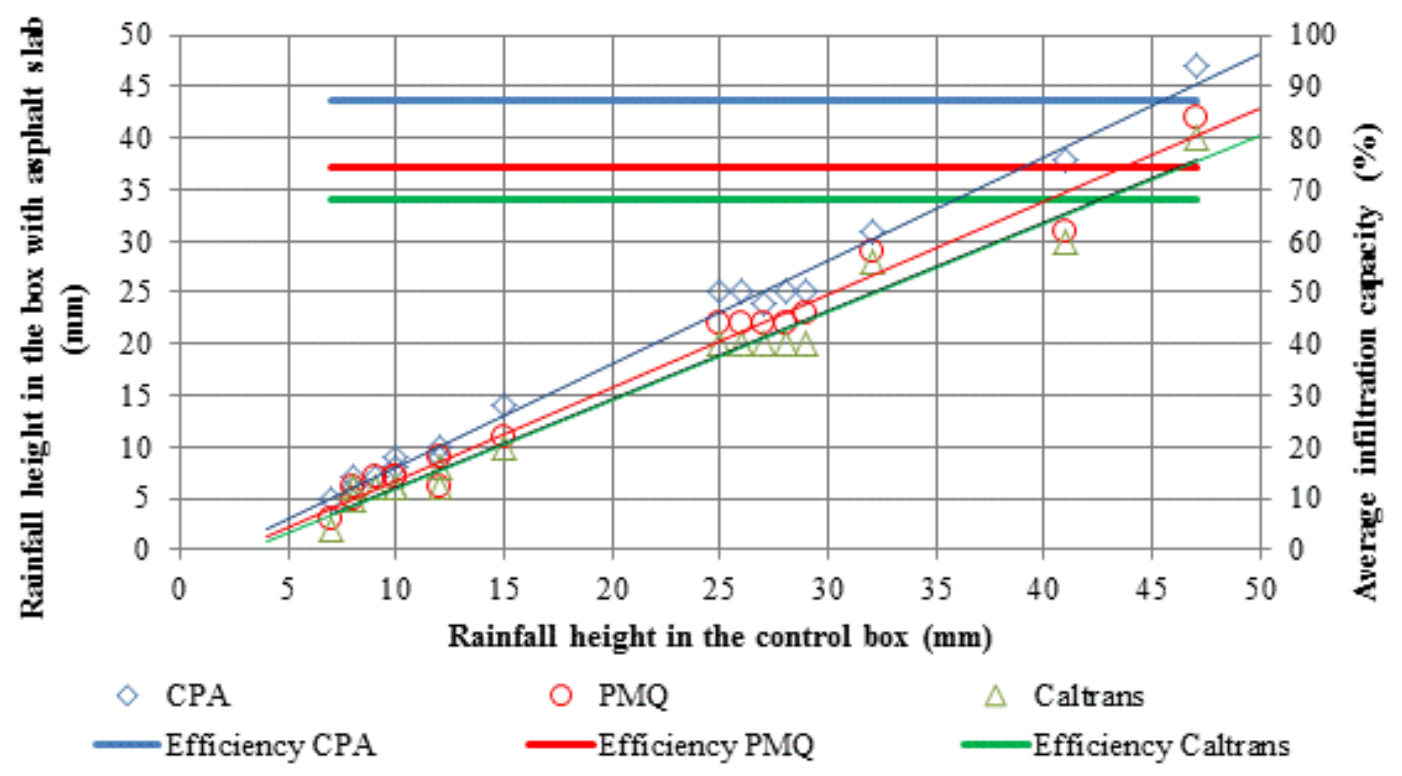

Figure 5. Infiltration capacity in porous asphalt mixtures slabs.

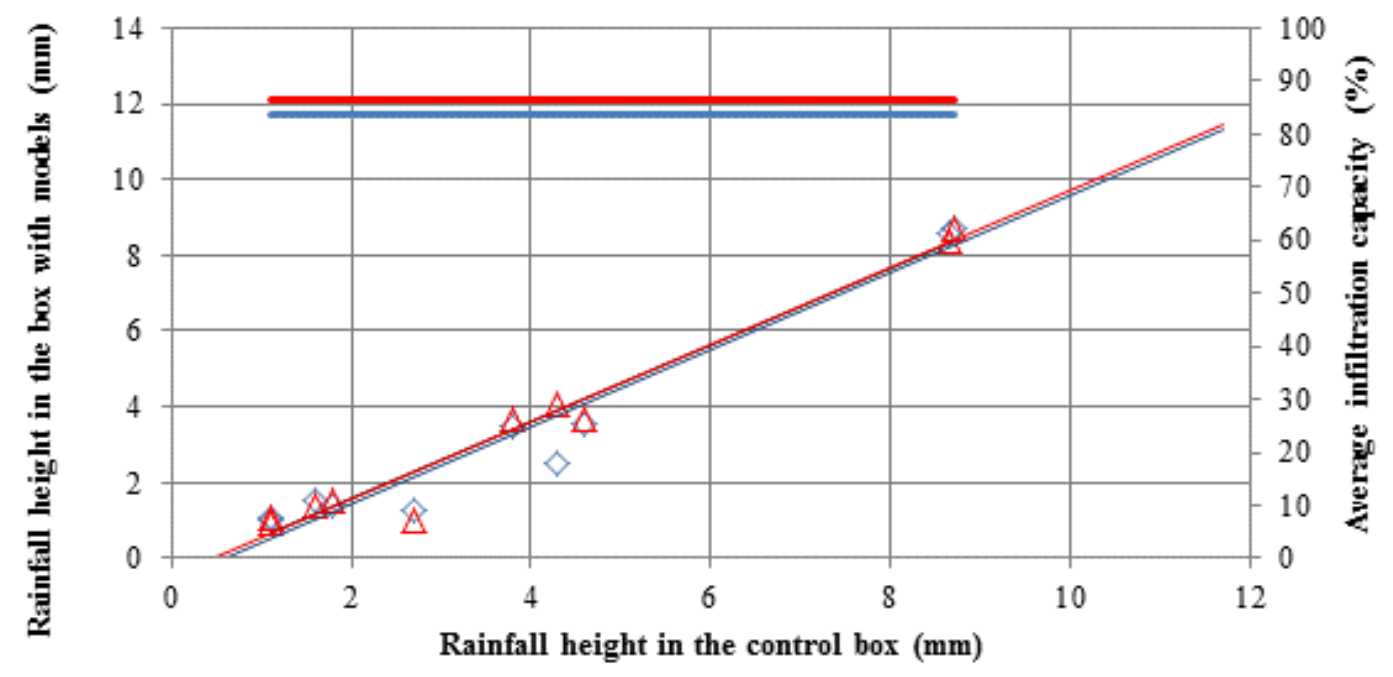

$\diamond$ Model A $\triangle$ Model B Effíciency Model A Efficiency Model B

Figure 6. Infiltration capacity in Models A and B.

Model B showed a slightly higher infiltration capacity in comparison to Model A ( $86.4 \%$ and $83.7 \%$, respectively). Model A has a porous layer (reservoir course) in aggregate base BGS with a high amount of fines, which reduces the draining capacity and contributes to reduce its infiltration 
capacity. On the other hand, the layers in Model B have a high permeability that results in a better draining capacity.

The possibility of water evaporation in the control box was not taken into account since the analyses were performed in less time than thirty minutes after each rainfall event. The collected sample complies with the Brazilian guide for water sample collection [42]. The main recommendations are: (i) the collection bottle should be opened only at the time of use, for the time required to fill it, and be closed immediately after collection; (ii) the collected samples must be wrapped in a thermal box and sent to the laboratory in the shortest time possible, and the maximum time elapsing between the collection and the test being $24 \mathrm{~h}$. As the laboratory is located next to the local for the collection, $30 \mathrm{~min}$ from the beginning of the rainfall event was the maximum interval of time chosen to perform the tests. Furthermore, boxes were sealed to prevent the infiltration of water through the lateral edges.

The relation between rainfall in asphalt mixture slabs and in the control, as well as stormwater in the models, is shown in the Appendix (Tables A6 and A7). Although the standard deviation was high for infiltration in the slabs and in the models, the same behaviour was observed in the control.

\subsection{Quality Analysis}

The water quality was analysed for Models A and B in each rainfall event. Results were compared to the limits recommended by: (a) ANA (2005) [31]; (b) CONAMA (2011) [32] and (c) CONAMA (2005) [33].

\subsubsection{Rainwater}

The rainwater infiltrated through the models was collected and its quality was compared with the quality of the rainwater collected from the control box. There was an increase in the $\mathrm{pH}$ in Models A and B; it was 5.8 in the control and it increased to 7.7 in Model A and 7.1 in Model B (See Figure A1 in the Appendix). As for phosphorus there was a great variation in its concentration (See Figure A2 in the Appendix). The average concentration was $0.20 \mathrm{mg} / \mathrm{L}$ in the control box, 0.54 in Model A and 0.94 in Model B, all above the permitted maximum $(0.1 \mathrm{mg} / \mathrm{L})$. The passage of rainwater through the models raised the $\mathrm{pH}$ value, which is desirable. However, the increasing of the phosphorus concentration indicates that such water can only be used after filtering.

In both models, the concentrations of iron and aluminium were greater than the control and also greater than the maximum limit. The average concentration of iron was $0.018 \mathrm{mg} / \mathrm{L}$ in the control, $0.349 \mathrm{mg} / \mathrm{L}$ in Model A and $0.538 \mathrm{mg} / \mathrm{L}$ in Model B (Figure A3 in the Appendix). The models increased the concentration of iron in the rainwater but it was still lower than the allowed limit (up to $15.0 \mathrm{mg} / \mathrm{L}$, [32]). The rainwater in the control presented average aluminium concentration equal to $0.026 \mathrm{mg} / \mathrm{L}$ while it was $0.12 \mathrm{mg} / \mathrm{L}$ in Model A and $0.08 \mathrm{mg} / \mathrm{L}$ in Model B. There was an increase in aluminium concentration when rainwater passed through the models, but such concentration was lower than the limit $(0.1 \mathrm{mg} / \mathrm{L})$ only in Model B (Figure A4 in the Appendix). There was an increase of concentrations of zinc and nitrite in the models compared to the control (Figures A5 and A6 in the Appendix). However, such concentrations were much lower than the limits of $5.0 \mathrm{mg} / \mathrm{L}$ [32] for zinc and $1.0 \mathrm{mg} / \mathrm{L}$ [34] for nitrite.

There was a great variation of ammonia concentration in the control box (Figure A7 in the Appendix); this may be due to the fact that the site is close to the sea. It was observed, in some events, that the models could reduce the concentration of ammonia in comparison to the control. In some cases, the models were capable of filtering this pollutant totally. For ammonia, ANA [31] established $20.0 \mathrm{mg} / \mathrm{L}$ as the maximum limit and such limit was not exceeded. Regarding dissolved oxygen, there was a decrease in some events compared to the control, but they were all above the minimum limit (Figure A8 in the Appendix).

For chromium concentrations, there were no significant changes after the passage of rainwater through the models (Figure A9 in the Appendix). In both models, the measured values were above the maximum limits for this pollutant $(1.0 \mathrm{mg} / \mathrm{L}$, [32]). The presence of copper was not verified in the samples (rainwater and water from the models). 


\subsubsection{Stormwater}

The stormwater infiltrated through the models was collected and its quality was compared with the quality of the stormwater from the control sample.

The $\mathrm{pH}$ values in both models and also in the control were within the limits (6.0 to 9.0, [31]). Comparing to control, in general, the $\mathrm{pH}$ decreased in Model $\mathrm{B}$ and increased in Model A (Figure A10 in the Appendix). The concentration of phosphorus in both models and also in the control was above the allowable maximum $(0.1 \mathrm{mg} / \mathrm{L}$, [31]). Higher concentrations were observed in Model B compared to control. On the other hand, Model A was capable of reducing the concentration of phosphorus in comparison to control in some events (Figure A11 in the Appendix).

The phosphorus concentrations were very high. The local conditions may have influenced the results, that is, near the place where the samples were collected there is a stream ( $5 \mathrm{~m}$ wide, $3 \mathrm{~m}$ deep and $2 \mathrm{~km}$ long) which is polluted by household waste. According to Quevedo (2015) [43], the concentration of phosphorus is more significant in heavily populated areas due to domestic sewage, especially by the use of detergents and soap.

Despite iron concentrations in the models were higher than the control, they were very low in comparison to the limit (15.0 mg/L, [32]) (Figure A12 in the Appendix). The metallic apparatus used to support the layers in the boxes that contain the models may have contributed to increase the iron contamination. This also resulted in high concentrations of aluminium, more than the limit $(0.1$ $\mathrm{mg} / \mathrm{L}$, [32]). Stormwater in the control had aluminium concentrations below the threshold and the concentrations increased after passing through the models (Figure A13 in the Appendix). It was observed that iron and aluminium concentrations in some measurements in Model A were lower than in Model B.

Both zinc and nitrite concentrations were lower than the limits (for maximum zinc $5.0 \mathrm{mg} / \mathrm{L}$, [32] and maximum nitrite $1.0 \mathrm{mg} / \mathrm{L}$, [31] (Figures A14 and A15 in the Appendix).

In general zinc concentrations increased after stormwater passed through the models. On the other hand, the models were able to reduce the concentration of nitrite in comparison to the control (stormwater collected directly from the street); Model B was more effective in filtering nitrite than Model A.

There was an increase of dissolved oxygen in all samples (Figure A16 in the Appendix). However, the models were able to reduce the concentration of ammonia in comparison to the control (Figure A17 in the Appendix). Although dissolved oxygen in Model B was lower than in Model A, its concentration was above the minimum established limit $(6.0 \mathrm{mg} / \mathrm{L},[33])$ in both models and also in the control.

For chromium, the concentrations were lower than the maximum limit $(1.0 \mathrm{mg} / \mathrm{L}$, [32]). In some cases, the models were capable of reducing copper concentrations in relation to the control. In many measurements, the cooper concentration was lower than the limit $(1.0 \mathrm{mg} / \mathrm{L}$, [32]) (Figures A18 and A19 in the Appendix).

\subsubsection{Discussion}

Regarding infiltration, it was observed that the porous mixtures and the models can be used as porous pavements with high infiltration capacity. Table 4 shows a summary of results for rainwater and also stormwater. Based on the results shown in Table 4 and also on the analyses of rainwater and stormwater quality, some points are discussed as follows.

Table 4. Average concentrations of all parameters and limits imposed by regulations.

\begin{tabular}{|c|c|c|c|c|c|c|}
\hline & Paramet & & Control & Model A & Model B & Limit \\
\hline \multirow{4}{*}{$\mathrm{pH}$} & \multirow{2}{*}{ Rainwater } & Average & 5.8 & 7.7 & 7.1 & \multirow{4}{*}{$6.0-9.0$} \\
\hline & & Standard deviation & 0.3 & 0.3 & 0.3 & \\
\hline & \multirow{2}{*}{ Stormwater } & Average & 6.9 & 7.6 & 7.6 & \\
\hline & & Standard deviation & 0.2 & 0.2 & 0.2 & \\
\hline
\end{tabular}




\begin{tabular}{|c|c|c|c|c|c|c|}
\hline \multirow{4}{*}{$\begin{array}{c}\text { Phosphorus } \\
\text { (mg/L) }\end{array}$} & \multirow{2}{*}{ Rainwater } & Average & 0.20 & 0.54 & 0.94 & \multirow{4}{*}{$\leq 0.10$} \\
\hline & & Standard deviation & 0.18 & 0.47 & 0.47 & \\
\hline & \multirow{2}{*}{ Stormwater } & Average & 0.92 & 1.26 & 3.19 & \\
\hline & & Standard deviation & 0.80 & 1.33 & 0.98 & \\
\hline \multirow{4}{*}{$\begin{array}{c}\text { Iron } \\
(\mathrm{mg} / \mathrm{L})\end{array}$} & \multirow{2}{*}{ Rainwater } & Average & 0.02 & 0.35 & 0.54 & \multirow{4}{*}{$\leq 15.00$} \\
\hline & & Standard deviation & 0.03 & 0.41 & 0.44 & \\
\hline & \multirow{2}{*}{ Stormwater } & Average & 0.54 & 0.81 & 2.12 & \\
\hline & & Standard deviation & 0.45 & 0.82 & 0.44 & \\
\hline \multirow{4}{*}{$\begin{array}{l}\text { Aluminium } \\
(\mathrm{mg} / \mathrm{L})\end{array}$} & \multirow{2}{*}{ Rainwater } & Average & 0.03 & 0.12 & 0.08 & \multirow{4}{*}{$\leq 0.10$} \\
\hline & & Standard deviation & 0.03 & 0.11 & 0.04 & \\
\hline & \multirow{2}{*}{ Stormwater } & Average & 0.05 & 0.13 & 0.18 & \\
\hline & & Standard deviation & 0.05 & 0.09 & 0.09 & \\
\hline \multirow{4}{*}{$\begin{array}{c}\text { Zinc } \\
(\mathrm{mg} / \mathrm{L})\end{array}$} & \multirow{2}{*}{ Rainwater } & Average & 0.01 & 0.05 & 0.04 & \multirow{4}{*}{$\leq 5.00$} \\
\hline & & Standard deviation & 0.01 & 0.06 & 0.04 & \\
\hline & \multirow{2}{*}{ Stormwater } & Average & 0.04 & 0.08 & 0.11 & \\
\hline & & Standard deviation & 0.07 & 0.10 & 0.05 & \\
\hline \multirow{4}{*}{$\begin{array}{l}\text { Nitrite } \\
(\mathrm{mg} / \mathrm{L})\end{array}$} & \multirow{2}{*}{ Rainwater } & Average & 0.01 & 0.02 & 0.04 & \multirow{4}{*}{$\leq 1.00$} \\
\hline & & Standard deviation & 0.01 & 0.01 & 0.02 & \\
\hline & \multirow{2}{*}{ Stormwater } & Average & 0.36 & 0.20 & 0.14 & \\
\hline & & Standard deviation & 0.16 & 0.08 & 0.09 & \\
\hline \multirow{4}{*}{$\begin{array}{c}\text { Ammonia } \\
(\mathrm{mg} / \mathrm{L})\end{array}$} & \multirow{2}{*}{ Rainwater } & Average & 0.14 & 0.07 & 0.14 & \multirow{4}{*}{$\leq 20.00$} \\
\hline & & Standard deviation & 0.08 & 0.08 & 0.10 & \\
\hline & \multirow{2}{*}{ Stormwater } & Average & 0.36 & 0.20 & 0.14 & \\
\hline & & Standard deviation & 0.16 & 0.08 & 0.09 & \\
\hline \multirow{4}{*}{$\begin{array}{c}\mathrm{DO} \\
(\mathrm{mg} / \mathrm{L})\end{array}$} & \multirow{2}{*}{ Rainwater } & Average & 9.0 & 8.8 & 8.8 & \multirow{4}{*}{$\geq 6.00$} \\
\hline & & Standard deviation & 0.0 & 0.4 & 0.4 & \\
\hline & \multirow{2}{*}{ Stormwater } & Average & 6.9 & 7.6 & 6.7 & \\
\hline & & Standard deviation & 0.2 & 0.2 & 0.2 & \\
\hline & Painurato & Average & 0.01 & 0.02 & 0.02 & \\
\hline Chromium & Namtwater & Standard deviation & 0.01 & 0.02 & 0.02 & ( \\
\hline$(\mathrm{mg} / \mathrm{L})$ & Stor & Average & 0.03 & 0.03 & 0.07 & \\
\hline & gentitvater & Standard deviation & 0.02 & 0.04 & 0.02 & \\
\hline & Rainwater & Average & 0.00 & 0.03 & 0.00 & \\
\hline Copper & Nantwater & Standard deviation & 0.00 & 0.08 & 0.00 & 190 \\
\hline$(\mathrm{mg} / \mathrm{L})$ & 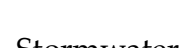 & Average & 0.32 & 0.30 & 0.37 & -1.00 \\
\hline & Gotintwater & Standard deviation & 0.47 & 0.44 & 0.40 & \\
\hline
\end{tabular}

After the stormwater passed through the models the $\mathrm{pH}$ value was patterned between the limits, which did not occur with rainwater. These results are similar to those found by Dirkens et al., (2002) [22] and Llopart-Mascaró et al., (2010) [24] shown in Table 1. The average and standard deviation (Table 4) showed that there were no high dispersions in the results. The same was observed in the stormwater analysis.

The concentration of phosphorus found in rainwater is higher than the limit but similar to that found in the literature $(0.01$ to $0.23 \mathrm{mg} / \mathrm{L})$. As for stormwater, the concentrations were higher than those found in the literature, which may indicate the influence of the region (next to the sea, where rainfall may contain more phosphorus concentrations). The models were unable to reduce 
phosphorus concentrations. However, the standard deviation was high, so that the sample values were not homogeneous.

Bean et al., (2007) [40] also observed that the concentrations of total phosphorus from rainwater were significantly lower than for stormwater. Tota-Maharaja et al., (2010) [39] verified that the phosphorus in stormwater filtered by the pavement system has to be removed via mechanical filtration and biological treatment in case such water is to be used.

Iron concentrations both in the rainwater and the stormwater were very low. The results were different than those found in the literature. After the passage of water through the models, despite the elevation in the concentrations, this was very small in comparison to the limit. It is important to consider that there was an increase in iron concentration in the water. Such an increase may be due to the metal support used in the boxes.

In relation to aluminium concentrations, rainwater and stormwater presented values lower than the limit. However, the concentration in Model A was, on average, a little higher than the limit for rainwater. For both models, concentrations in stormwater were higher than the control. The standard deviation was similar to the average. In research conducted in Australia, the stormwater monitoring resulted in aluminium concentrations ranging from 0.032 to $0.056 \mathrm{mg} / \mathrm{L}$ [40], higher than the concentrations obtained in this study.

The concentration of zinc in rainwater increased after the rainwater passed through the models. However, this was insignificant in comparison to the limits. The concentration in the control was lower than that found in the literature $(0.52 \mathrm{mg} / \mathrm{L})$. As for stormwater, the models decreased the concentration of zinc. Despite the nitrite concentrations found in the rainwater and the stormwater, the values did not reach the limits. The models were able to retain that parameter. Nitrite concentration in the stormwater can range from 0.005 to $0.012 \mathrm{mg} / \mathrm{L}$ [40].

Ammonia concentrations measured in the rainwater and the stormwater were much lower than the limit. These values match those found in the literature, i.e., 0.10 to $2.0 \mathrm{mg} / \mathrm{L}$ in stormwater and 0.5 to $2.3 \mathrm{mg} / \mathrm{L}$ in rainwater [22]. The models showed to be able to filter ammonia.

In a parking lot located in New Jersey, the U.S. Environmental Protection Agency constructed porous pavement sections $\left(54.9 \mathrm{~m}^{2}\right.$ each) that direct stormwater into $5.7 \mathrm{~m}^{3}$ tanks. The sections were: porous interlocking concrete pavement (PICP), porous concrete (PC), and porous asphalt (PA). Brow and Borst (2015) [44] collected samples in the tanks and in situ from 13 rainfall/runoff events during 12 months. The water was analysed for nitrogen species, orthophosphate, and organic carbon. According to the authors, contrary to assumptions based on the literature, the PA samples had significantly larger total nitrogen concentrations than runoff and samples from the others porous pavement types, indicating that nitrogen leached from materials in the PA layer. Also, there was no great difference in total nitrogen concentration between runoff and samples from either PICP or PC, but total nitrogen was significantly higher in runoff than in rainwater. Nitrate was the dominant nitrogen species in the samples. The PA sample had significantly higher nitrite and ammonia concentrations than PICP and PC. Contrary to the nitrogen results, the PA sample had significantly smaller orthophosphate concentrations than rainwater, runoff, and samples from PICP and PC. The results have shown that such porous pavement systems do not reduce total nitrogen concentrations from stormwater runoff due to the lack of anaerobic conditions.

Dissolved oxygen refers to the level of free, non-compound oxygen present in water. According to Brazilian regulations the minimum limit is $6.0 \mathrm{mg} / \mathrm{L}$. Results indicate that dissolved oxygen remained above the limit. In rainwater, the values measured by Chughtai et al., (2014) [45] varied from 6.3 to $8.2 \mathrm{mg} / \mathrm{L}$, that is, similar to those found in this study.

For chromium and cooper, the concentrations measured were lower than the limits. For rainwater, the concentration was similar to that found by Llopart-Mascaró et al., (2010) [24].

From the analysis of pollutants it was observed that the rainwater and the stormwater in Florianópolis are not significantly contaminated. 
The data presented in this work are part of a greater research program, still in progress. The next steps of the research include measurements that will be performed in several places where the presence of contaminants may differ from those shown herein. Also, each pavement material layer will be tested separately in order to quantify the effects of each material in the testing setup. Many different layers will be tested. Distilled water will also be used.

Another important assessment that has to be made is the measurement of water quality in different seasons, as Drake et al., (2014) [17] and Cederkvist et al., (2017) [46] studied.

\section{Conclusions}

This study assessed porous pavement structures in order to evaluate their capability to reduce pollutants concentrations. Both models showed high infiltration capacity, but Model B showed a slightly higher infiltration capacity in comparison to Model A $(86.4 \%$ for B and $83.7 \%$ for A, on average), since Model A has a porous layer (reservoir course) in BGS with a higher percentage of fines (lower than $2.0 \mathrm{~mm}$ ), which may reduce the draining capacity and the model efficiency.

For rainwater quality analyses, after the passage through the models, the concentration of the following parameters, on average, increased in comparison to the control: phosphorus, iron, aluminium, zinc, nitrite, chromium and cooper. For phosphorus and aluminium the concentrations exceeded the established limits; phosphorus concentration also exceeded the limit in the control. Regarding $\mathrm{pH}$, it increased and was within the established limits, which did not occur in the control, whose value was below the established limit. In relation to dissolved oxygen, there was no significant difference between the models and the control. Model A was able to reduce the concentration of ammonia.

For stormwater, the same was observed for both models. The concentrations of phosphorus, iron, aluminium, zinc, nitrite, chromium and cooper increased in comparison to the control. The $\mathrm{pH}$ value increased after stormwater passed through the models. Only for phosphorus and aluminium did the concentrations exceeded the limits. Both models were capable of filtering, and reduced the ammonia concentration.

No odours or variation of the rainwater and stormwater aspect of the models were detected in comparison to the control. Also, no fecal coliforms were detected either in rainwater or stormwater tests.

It was observed that the rainwater and the stormwater collected in Florianópolis are not significantly polluted. It was also possible to conclude that it is possible to collect stormwater from asphalt porous surfaces and porous pavements for non-potable purposes. From this study it was possible to identify and quantify what pollutants are present in rainwater and stormwater. However, the standards used herein are meant for non-potable uses and therefore restrictive. Nevertheless, it was possible to quantify several pollutants whose concentrations could either be increased or decreased after passing through the models, allowing for the selection of proper treatment in case such water is to be used.

The models tested showed the ability to filter out, from stormwater and rainwater, a few pollutants, but not all of them. However, porous pavements are still an alternative to harvest rainwater for non-potable uses and to recharge the water table. Also, for the implantation of porous pavements it is important to avoid their proximity to potential sources of pollutants such as sewers, polluted rivers and landfills.

Author Contributions: Liseane P. Thives and Enedir Ghisi designed the models, while Douglas G. Brecht and Dario M. Pires performed the experiments. All authors wrote the paper.

Conflicts of Interest: The authors declare no conflict of interest. 


\section{Appendix A. Supplementary Data}

Table A1. Characterization of Aggregates.

\begin{tabular}{cccc}
\hline \multirow{2}{*}{ Parameter } & \multicolumn{2}{c}{ Coarse Aggregates } & Fine Aggregates \\
\cline { 2 - 4 } & $\mathbf{3 / 4 ^ { \prime \prime }}$ & $\mathbf{3 / \mathbf { 8 } ^ { \prime \prime }}$ & $<\mathbf{4 . 7 5} \mathbf{~ m m}$ \\
\hline Apparent specific gravity (Gsa) & 2.774 & 2.740 & 2.717 \\
Bulk specific gravity (Gsb) & 2.748 & 2.701 & - \\
Absorption (\%) & 0.351 & 0.521 & - \\
\hline
\end{tabular}

Table A2. Characterization of asphalt rubber.

\begin{tabular}{cccc}
\hline Parameter & Standard & Specification & Results \\
\hline Penetration 25oC, 100 g, 5 s (0.01 mm) & ASTM D5 & 25 to 75 & 42.0 \\
Softening point (oC) & ASTM D 36 & 54.4 min. & 67.7 \\
Apparent viscosity (cP) 175oC & ASTM D 2196 & 1500 min. & 1644 \\
Resilience (\%) & ASTM D 5329 & 20.0 min. & 33.0 \\
RTFOT 163oC, 85 min & ASTM D 2872 & & \\
Change in mass (\%) & ASTM D 2872 & 0.6 max. & 0.3 \\
Softening point (oC) & ASTM D 36 & - & 2.9 \\
Penetration 25oC, 100 g, 5 s (0.01 mm) & ASTM D5 & - & 25.3 \\
Retained penetration (\%) & ASTM D 2872 & - & 60.2 \\
Apparent viscosity (cP) 175oC & ASTM D 2196 & - & 1962 \\
Resilience (\%) & ASTM D5 & - & 32.0 \\
\hline
\end{tabular}

Table A3. Aggregate gradation specifications and gradation curves.

\begin{tabular}{cccccccc}
\hline \multirow{2}{*}{ Sieves } & \multicolumn{3}{c}{ Specifications } & \multicolumn{3}{c}{ Gradation Curves } \\
\cline { 3 - 8 } & & \multicolumn{3}{c}{ \% Passing } & \multicolumn{3}{c}{ \% Passing } \\
\hline Inches/No & mm & Caltrans & CPA & PMQ & Caltrans & CPA & PMQ \\
\hline $3 / 4^{\prime \prime}$ & 19.0 & 100 & - & 100 & 100 & - & 100 \\
$5 / 8^{\prime \prime}$ & 16.0 & - & - & $88-100$ & - & - & 94 \\
$1 / 2^{\prime \prime}$ & 12.5 & $95-100$ & 100 & $78-94$ & 97.5 & 100 & 86 \\
$3 / 8^{\prime \prime}$ & 9.5 & $79-89$ & $70-90$ & $60-80$ & 83 & 90 & 70 \\
No. 4 & 4.8 & $28-37$ & $15-30$ & $44-60$ & 32 & 30 & 52 \\
No. 10 & 2.0 & - & $10-22$ & - & - & 16 & - \\
No. 8 & 2.4 & $7-18$ & - & - & - & - & - \\
No. 40 & 0.4 & - & $6-13$ & $20-35$ & 12.5 & 11 & 27 \\
No. 30 & 0.6 & $0-10$ & - & - & - & - & - \\
No. 80 & 0.18 & - & - & $12-24$ & 6.5 & - & 18 \\
No. 200 & 0.075 & $0-3$ & $3-6$ & $9-12$ & 1.5 & 4 & 1.5 \\
\hline
\end{tabular}

Table A4. Porous layers gradation specifications.

\begin{tabular}{|c|c|c|c|c|c|}
\hline Siev & & \multicolumn{4}{|c|}{ Porous Layers } \\
\hline \multirow[t]{2}{*}{ Inches/No } & \multirow[t]{2}{*}{$\mathrm{mm}$} & $\begin{array}{l}\text { Choker Course } \\
\text { (UNHSC, 2009) }\end{array}$ & $\begin{array}{c}\text { Filter Course } \\
\text { (UNHSC, 2009) }\end{array}$ & $\begin{array}{c}\text { Reservoir Course } \\
\text { (UNHSC, 2009) }\end{array}$ & $\begin{array}{c}\text { BGS (Grade C) } \\
\text { (Brazil, 2016) }\end{array}$ \\
\hline & & \multicolumn{4}{|c|}{$\%$ Passing } \\
\hline $21 / 2^{\prime \prime}$ & 63.0 & - & - & 100 & - \\
\hline $2^{\prime \prime}$ & 500.0 & - & - & 90-100 & - \\
\hline
\end{tabular}




\begin{tabular}{cccccc}
$11^{1 / 2}$ & 37.5 & 100 & - & $35-70$ & - \\
$1^{\prime \prime}$ & 25.0 & $95-100$ & - & $0-15$ & 100 \\
$3 / 4^{\prime \prime}$ & 19.0 & - & - & - & - \\
$1 / 2 "$ & 12.5 & $25-60$ & - & $0-5$ & - \\
$3 / 8^{\prime \prime}$ & 9.5 & - & 100 & - & $50-85$ \\
No. 4 & 4.8 & $0-10$ & $70-100$ & - & $35-65$ \\
No. 10 & 2.0 & - & - & - & $40-70$ \\
No. 8 & 2.4 & $0-5$ & - & - & - \\
No. 40 & 0.42 & - & - & - & $35-45$ \\
No. 200 & 0.075 & - & $0-6$ & - & $10-25$ \\
\hline
\end{tabular}

Table A5. Porous layers gradation specifications.

\begin{tabular}{|c|c|c|c|c|c|c|}
\hline \multirow[b]{2}{*}{ Layers } & \multicolumn{3}{|c|}{ Model A } & \multicolumn{3}{|c|}{ Model B } \\
\hline & Name & $\begin{array}{c}\text { Thickness } \\
(\mathrm{cm})\end{array}$ & Specification & Name & $\begin{array}{l}\text { Thickness } \\
(\mathrm{cm})\end{array}$ & Specification \\
\hline Surface & CPA & 7.0 & $\begin{array}{c}\text { DNER-ES } \\
386 / 99 \\
\end{array}$ & Caltrans & 7.0 & $\begin{array}{l}\text { Caltrans } \\
\text { OPFG 1/2" }\end{array}$ \\
\hline Choker course & PMQ & 5.0 & PMSP-ESP10/92 Grade I & $\begin{array}{l}\text { Choker } \\
\text { course }\end{array}$ & 5.0 & $\begin{array}{l}\text { UNHSC } \\
(2009)\end{array}$ \\
\hline Filter course & - & - & - & $\begin{array}{l}\text { Filter } \\
\text { course }\end{array}$ & 15.0 & $\begin{array}{l}\text { UNHSC } \\
(2009)\end{array}$ \\
\hline Reservoir course & BGS & 15.0 & DNIT 031/2006-ES & $\begin{array}{c}\text { Reservoir } \\
\text { course }\end{array}$ & 16.0 & $\begin{array}{l}\text { UNHSC } \\
(2009)\end{array}$ \\
\hline Total thickness & (cm) & 27.0 & & & 43.0 & \\
\hline
\end{tabular}

Table A6. Relation between rainfall infiltration capacity in the slabs and control.

\begin{tabular}{lcccc}
\hline \multirow{2}{*}{ Parameters } & \multicolumn{3}{c}{ Asphalt Mixtures Slabs } & Rainfall in the \\
\cline { 2 - 4 } & Caltrans & CPA & PMQ & Control (mm) \\
\hline Maximum infiltration capacity (mm) & 40.0 & 47.0 & 43.0 & 47.0 \\
Minimum infiltration capacity (mm) & 2.0 & 5.0 & 3.0 & 5.0 \\
Average infiltration capacity (mm) & 14.9 & 18.5 & 16.1 & 20.4 \\
Standard deviation (mm) & 10.9 & 10.8 & 9.9 & 9.3 \\
\hline
\end{tabular}

Table A7. Relation between stormwater infiltration in the models and control.

\begin{tabular}{cccc}
\hline \multirow{2}{*}{ Parameters } & \multicolumn{2}{c}{ Models } & \multirow{2}{*}{ Rainfall in the Control (mm) } \\
\cline { 2 - 3 } & A & B & \\
\hline Maximum infiltration capacity $(\mathrm{mm})$ & 8.7 & 8.7 & 8.7 \\
Minimum infiltration capacity $(\mathrm{mm})$ & 1.0 & 1.0 & 1.1 \\
Average infiltration capacity $(\mathrm{mm})$ & 3.3 & 3.5 & 3.8 \\
Standard deviation $(\mathrm{mm})$ & 2.2 & 2.3 & 2.2 \\
\hline
\end{tabular}




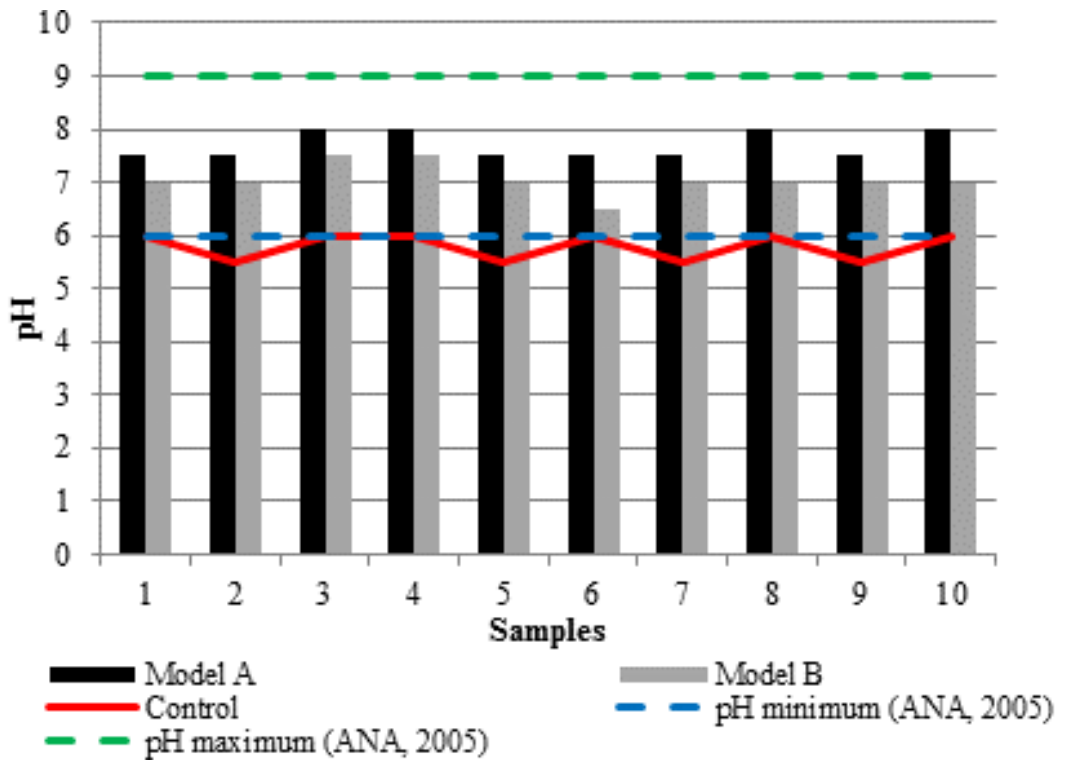

Figure A1. $\mathrm{pH}$ in rainwater samples for Models A and B.

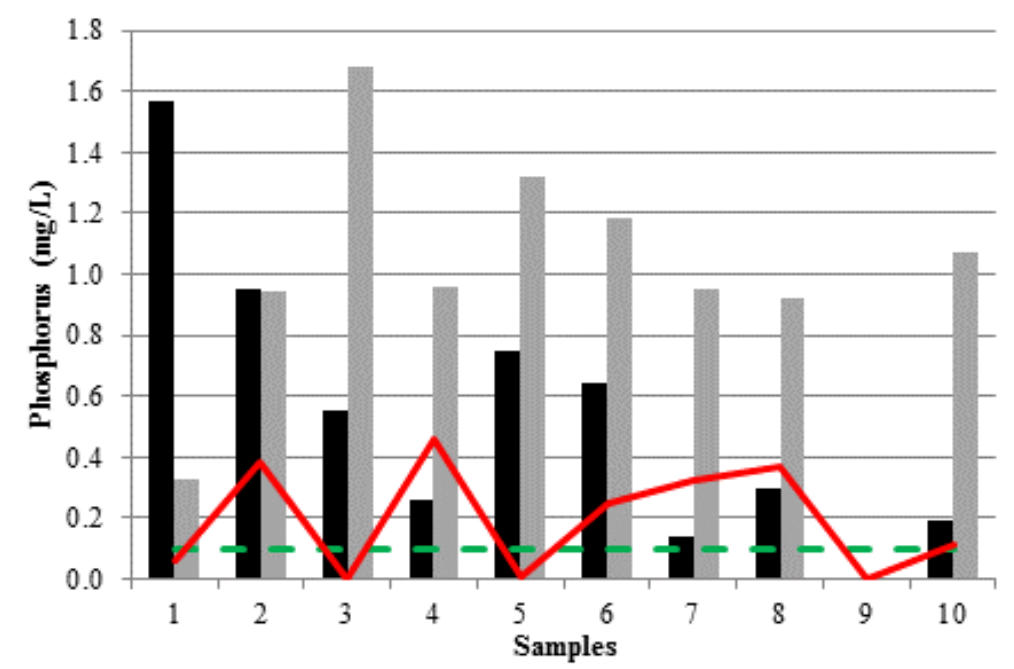

Model A Model B - - Phosphorus maximum (ANA, 2005) Control

Figure A2. Phosphorus in rainwater samples for Models A and B.

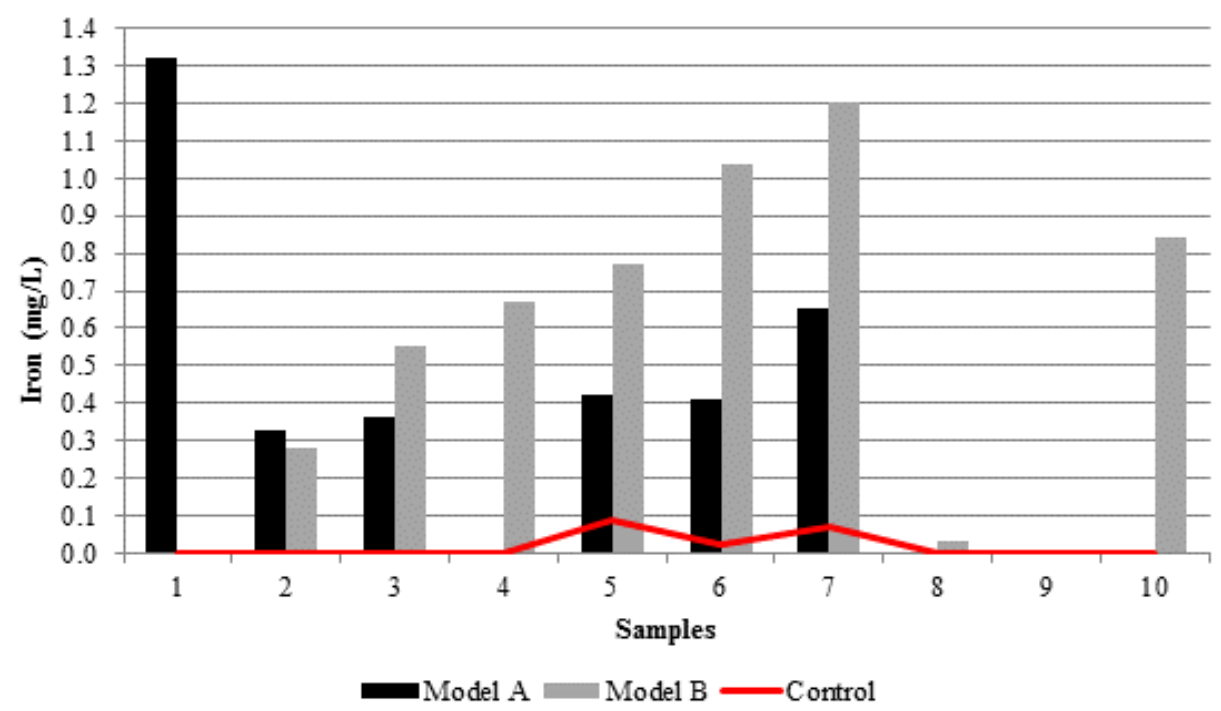

Figure A3. Iron in rainwater samples for Models A and B. 


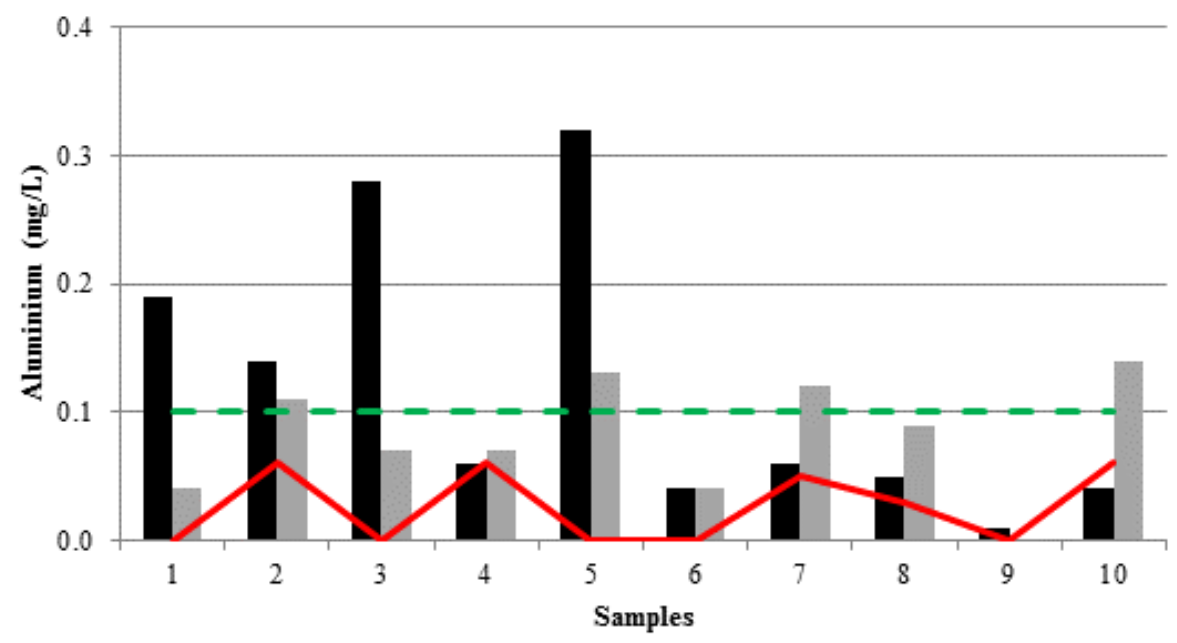

Model A Model B - - Aluminium max.(CONAMA, 2005)

Control

Figure A4. Aluminium in rainwater samples for Models A and B.

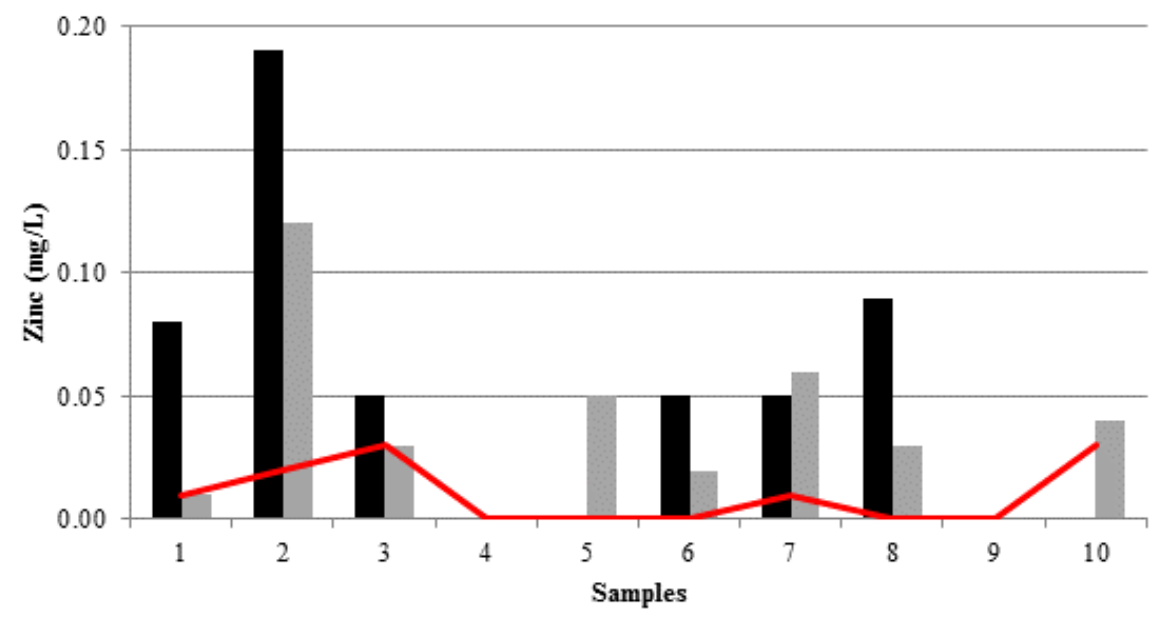

Model A Model B Control

Figure A5. Zinc in rainwater samples for Models A and B.

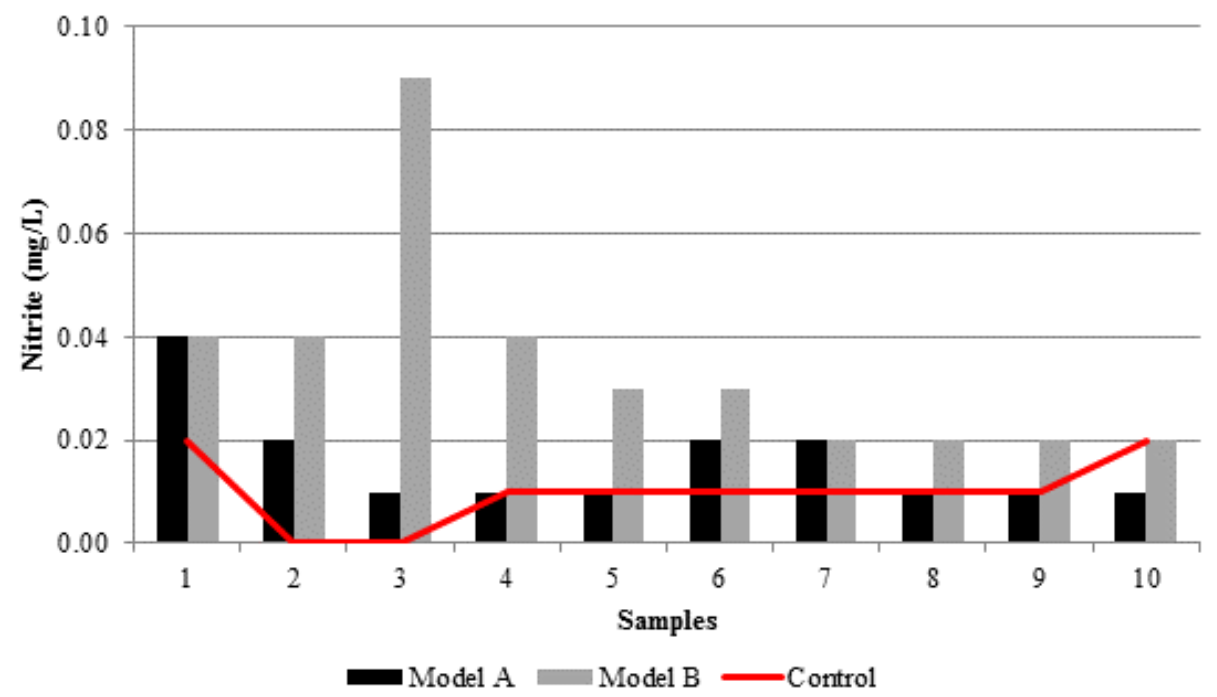

Figure A6. Nitrite in rainwater samples for Models A and B. 


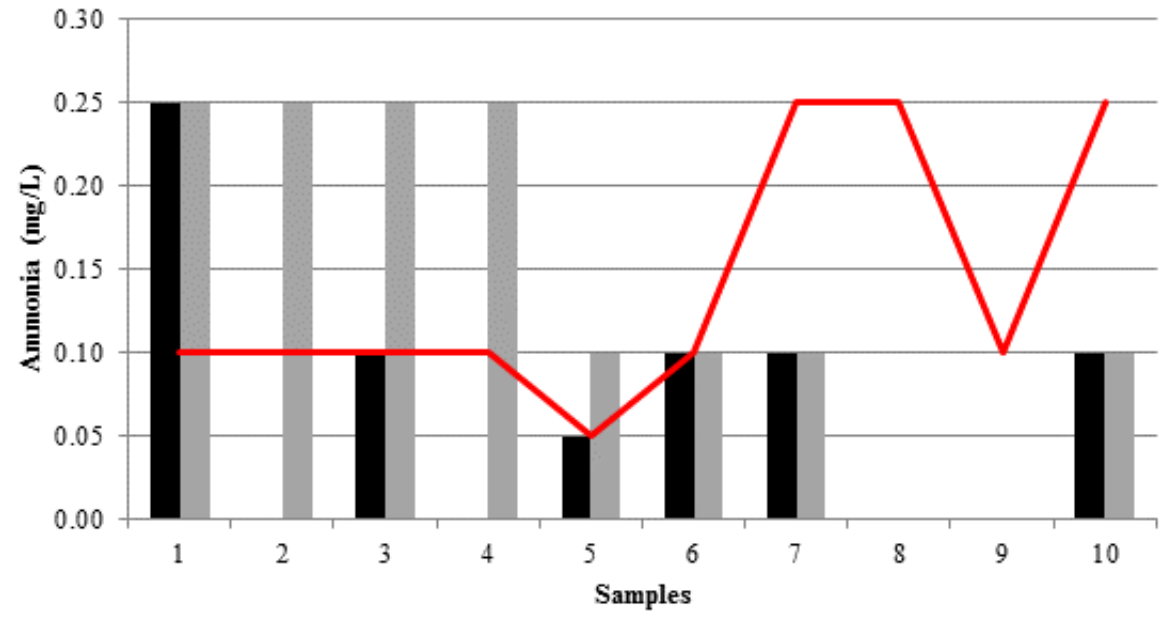

Model A Model B Control

Figure A7. Ammonia in rainwater samples for Models A and B.

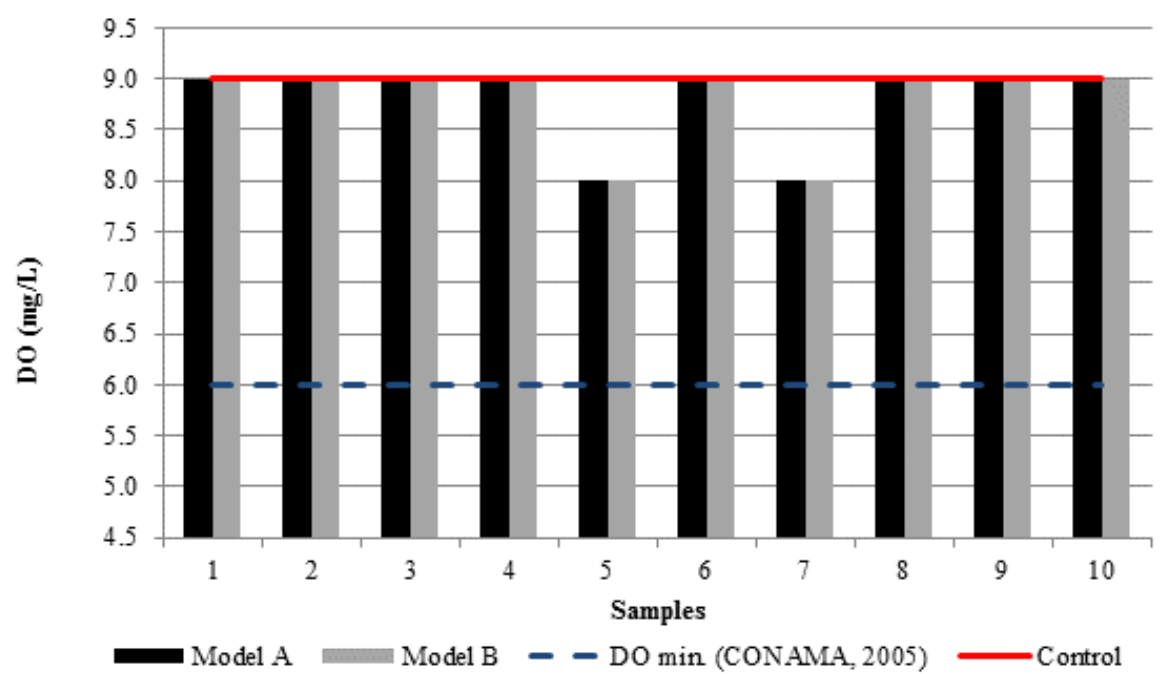

Figure A8. Dissolved oxygen (DO) in rainwater samples for Models A and B.

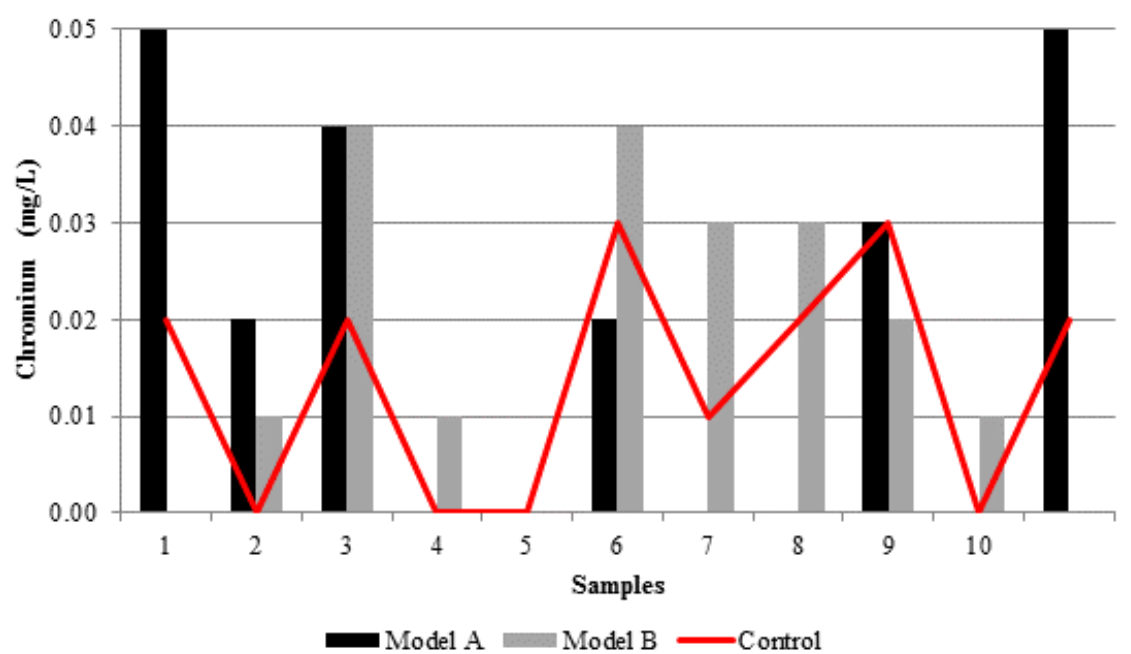

Figure A9. Chromium in rainwater samples for Models A and B. 


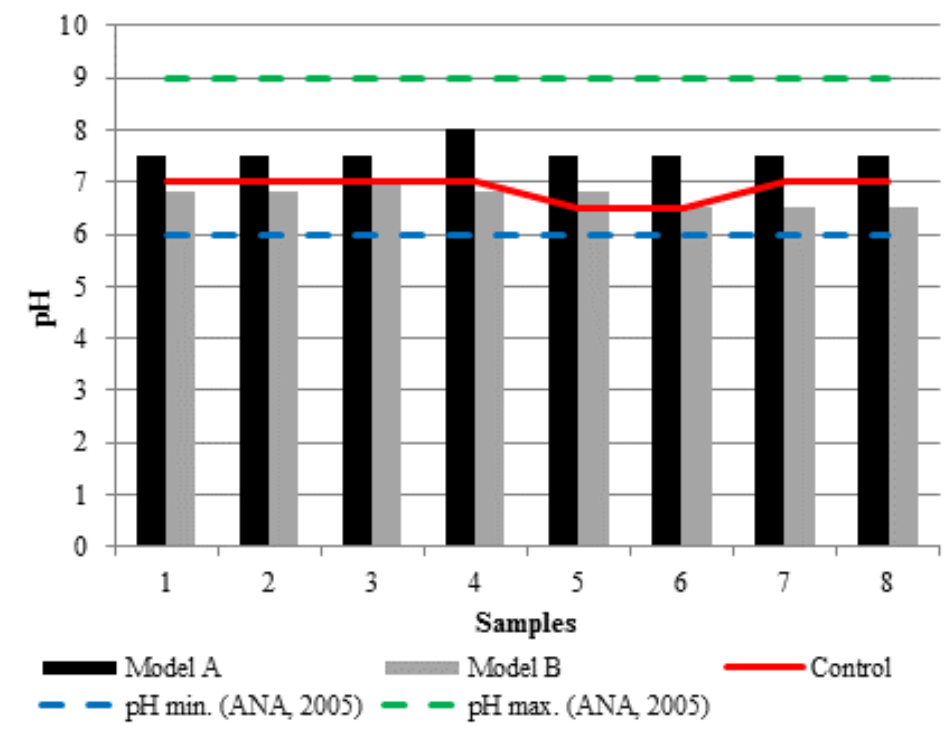

Figure A10. $\mathrm{pH}$ in stormwater samples for Models A and B.

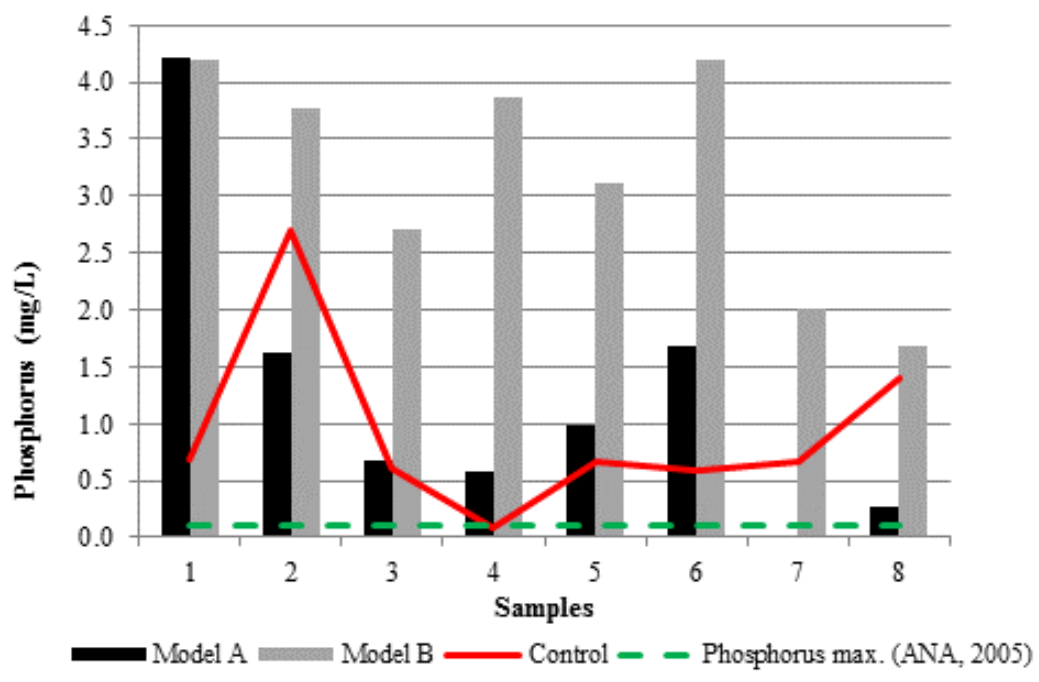

Figure A11. Phosphorus in stormwater samples for Models A and B.

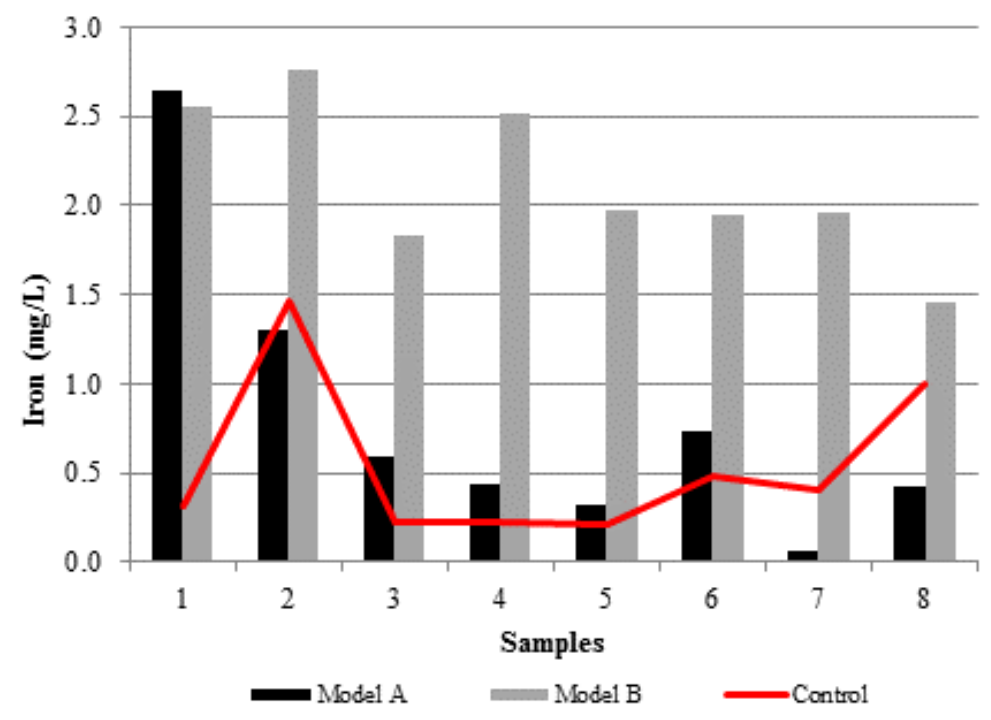

Figure A12. Iron in stormwater samples for Models A and B. 


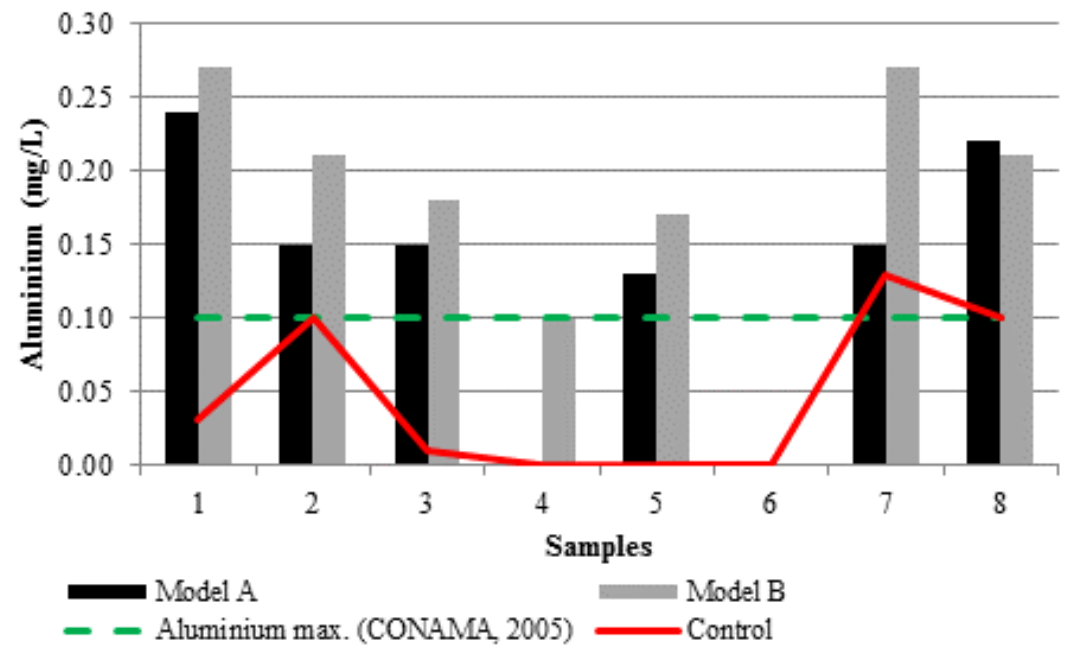

Figure A13. Aluminium in stormwater samples for Models A and B.

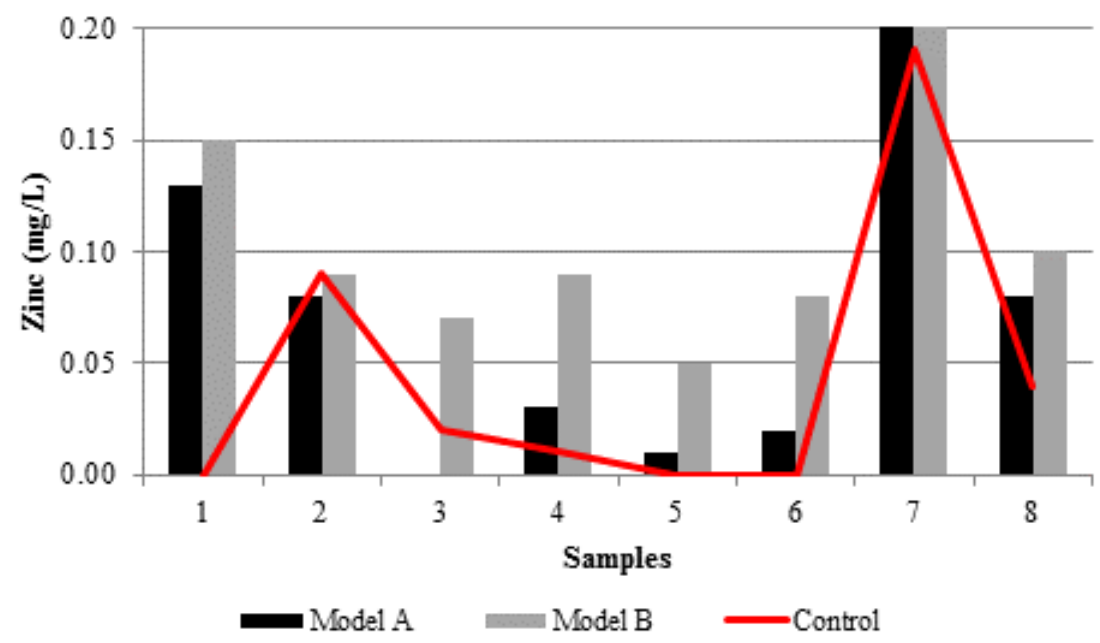

Figure A14. Zinc in stormwater samples for Models A and B.

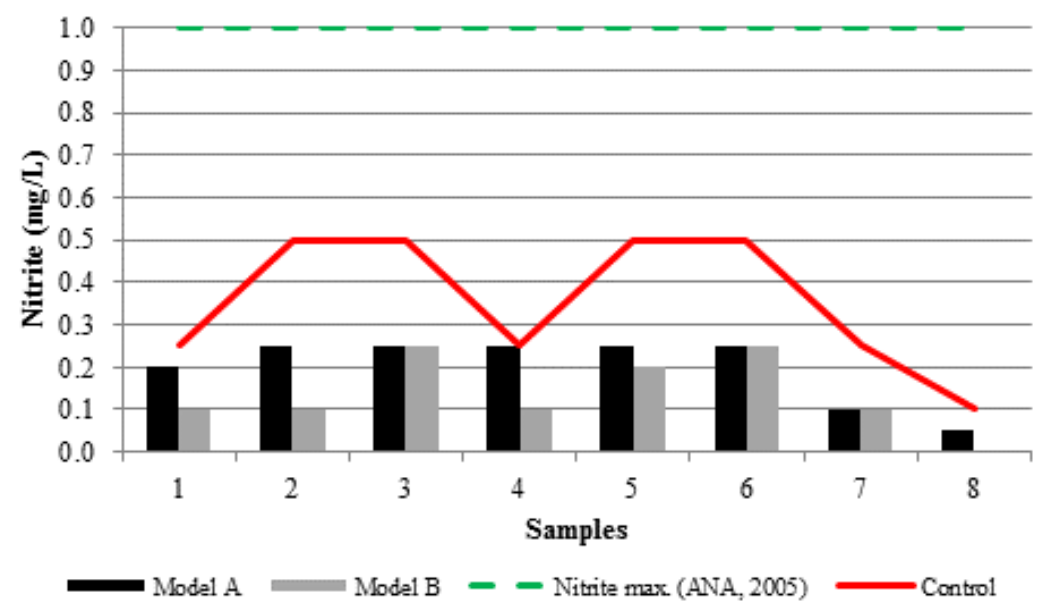

Figure A15. Nitrite in stormwater samples for Models A and B. 


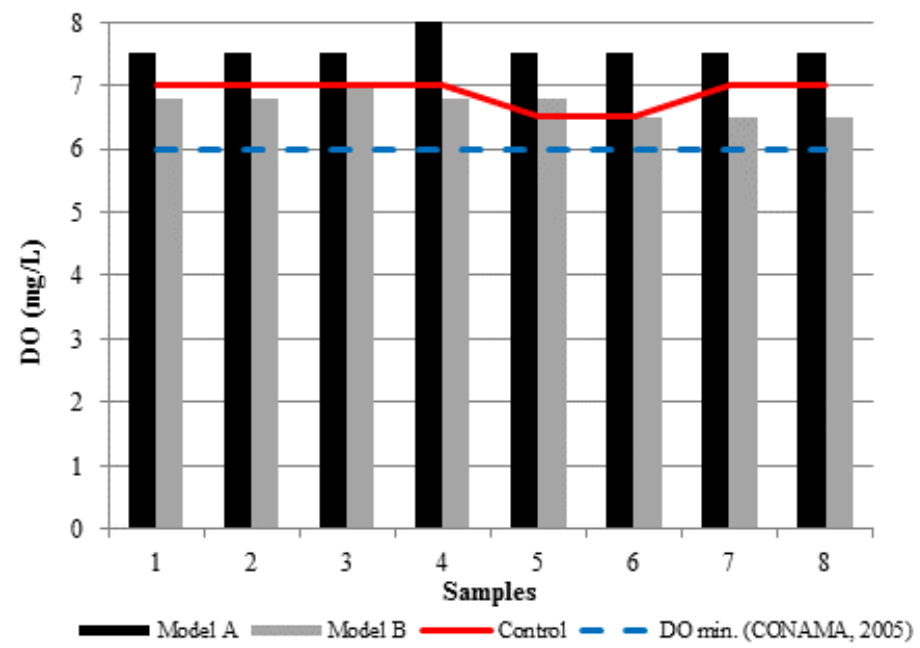

Figure A16. Dissolved oxygen (DO) in stormwater samples for Models A and B.

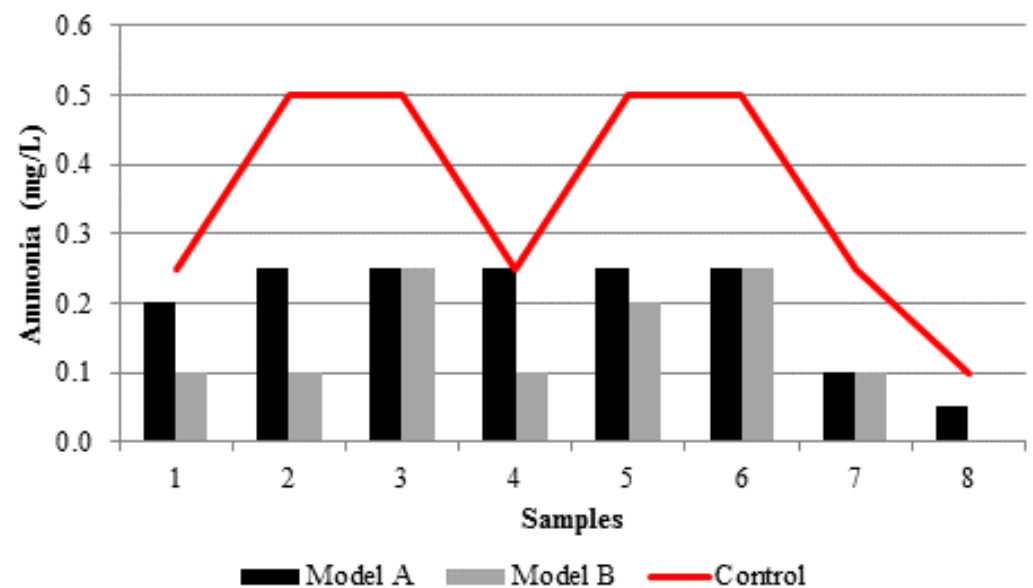

Figure A17. Ammonia in stormwater for Models A and B.

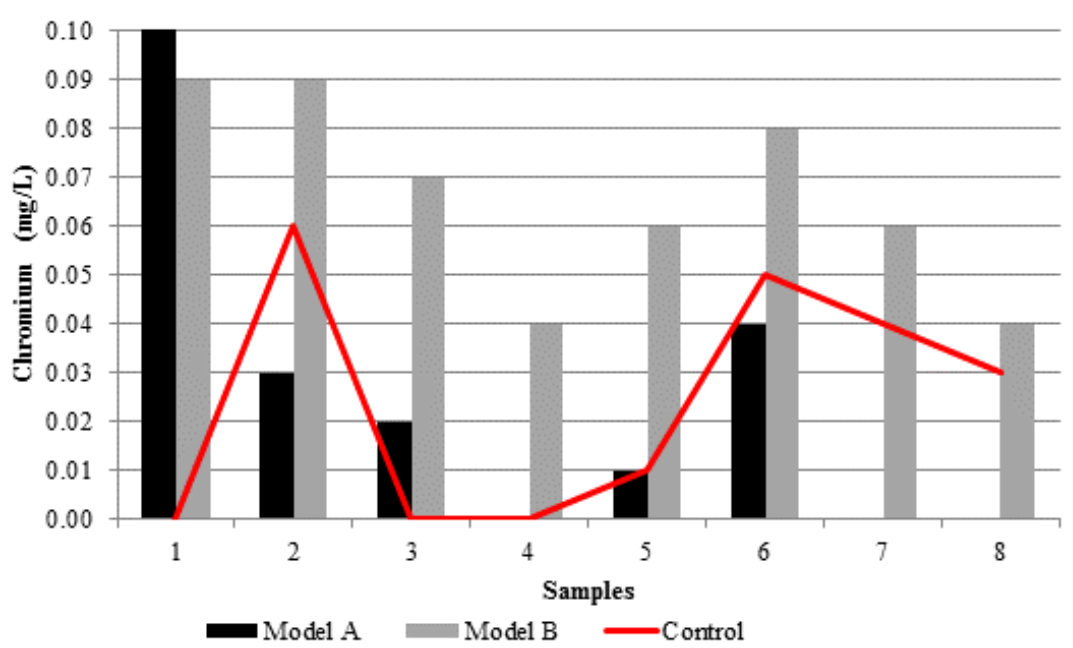

Figure A18. Chromium in stormwater samples for Models A and B. 


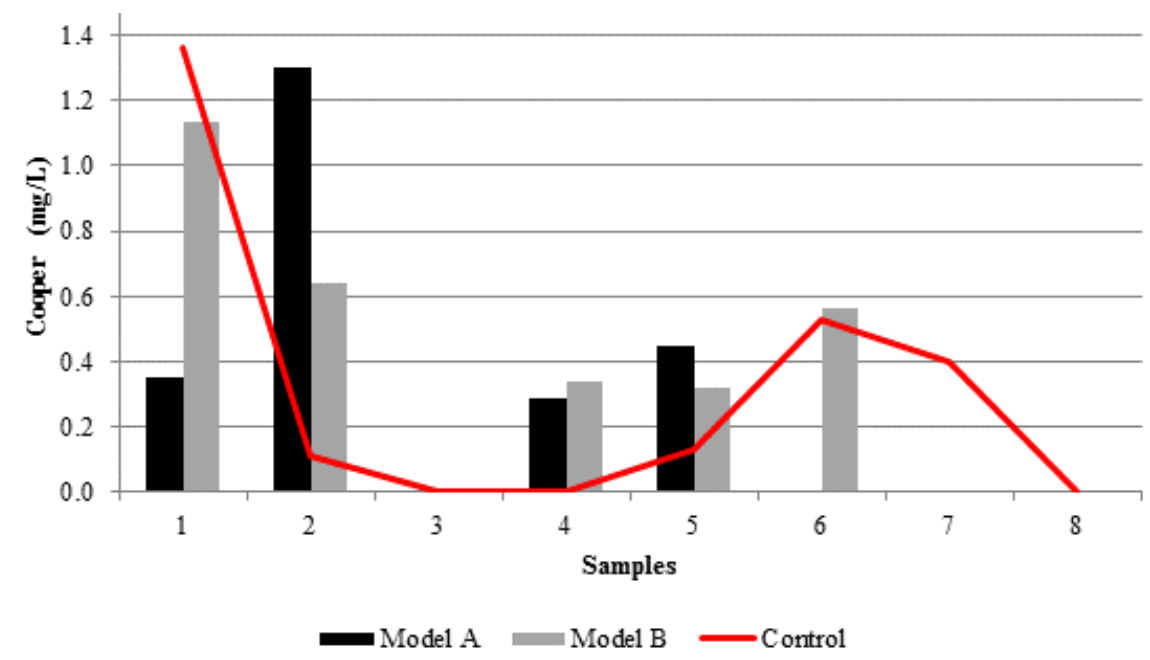

Figure A19. Cooper in stormwater samples for Models A and B.

\section{References}

1. Klenzendorf, J.B.; Eck, J.B.; Charbeneau, J.R.; Barret, E.M. Quantifying the behavior of porous asphalt overlays with respect to drainage hydraulics and runoff water quality. Environ. Eng. Geosci. 2012, XVIII, 99-111.

2. Tilley, J.S.; Slonecker, T.E. Quantifying the Components of Impervious Surfaces; Open File Report 2007-1008 U.S.; Department of the Interior, U.S. Geological Survey U.S. Geological Survey: Reston, VA, USA, 2006. Available online: https://pubs.usgs.gov/of/2007/1008/ofr2007-1008.pdf (accessed on 23 May 2017).

3. Green, O.O.; Shuster, W.D.; Rhea, L.K.; Garnestani, A.S.; Thurston, H.W. Identification and induction of human, social, and cultural capitals through an experimental approach to stormwater management. Sustainability 2012, 4, 1669-1682. Available online: http://www.mdpi.com/2071-1050/4/8/1669. (accessed on 25 May 2017).

4. Castro-Fresno, D.; Andrés-Valeri, V.C.; Sañudo-Fontanela, L.A.; Hernadez-Rodrigues, J. Sustainable drainage practices in Spain, specially focused on pervious Pavements. Water 2013, 5, 67-93. Available online: http://www.mdpi.com/2073-4441/5/1/67. (accessed on 15 Jul 2017).

5. Schaus, L.K. Porous Asphalt Pavement Designs: Proactive Design for Cold Climate Use. Master's Thesis, University of Waterloo, Waterloo, ON, Canada, 2007.

6. Suzuki, C.Y.; Azevedo, A.M.; Kabbach Júnior, F.I. Drenagem Subsuperficial de Pavimentos-Conceitos e Dimensionamento (Subsurface Drainage Pavements - Concepts and Design); Oficina de Textos: São Paulo, SP, Brazil, 2013; ISBN 978-85-7975-075. (In Portuguese).

7. Boogaard, F.; Lucke, T.; van de Giesen, N.; van de Ven, F. Evaluating the infiltration performance of eight Dutch permeable pavements using a new full-scale infiltration testing method. Water 2014, 6, 2070-2083. Available online: http://www.mdpi.com/2073-4441/6/7/2070 (accessed on 3 Aug 2017).

8. Lucke, T.; Beecham, S.; Boogaard, F.; Baden, M. Are infiltration capacities of clogged permeable pavements still acceptable? In Proceedings of the Novatech 2013-8th International Conference on planning and technologies for sustainable management of water in the city, Lyon, France, June 28-July 1 2013.

9. NAPA. Porous Asphalt Pavement; National Asphalt Pavement Association: Lanham, MD, USA, 2003.

10. Huber, G. Performance survey on open-graded friction course mixes. In Synthesis of Highway Practice 284; National Cooperative Highway Research Program (NCHRP): Washington, DC, USA, 2000.

11. Kiran, T.-M.; Parneet, P. Sustainable approaches for stormwater quality improvements with experimental geothermal paving systems. Sustainability 2015, 7, 1388-1410. Available online: http://www.mdpi.com/2071-1050/7/2/1388 (accessed on 20 May 2017).

12. Pratt, C.J.; Mantle, J.D.; Schofield, P.A. UK research into the performance of permeable pavement, reservoir structures in controlling stormwater discharge quantity and quality. Water Sci. Technol. 1995, 32, 63-69. 
13. Kumar, K.; Kozak, J.; Hundal, L.; Cox, A.; Zhang, H. In-situ infiltration performance of different permeable pavements in an employee used parking lot-A four-year study. J. Environ. Manag. 2016, 167, 8-14.

14. Siriwardene, N.; Deletic, A.; Fletcher, T. Modelling of sediment transport through stormwater gravel filters over their lifespan. Environ. Sci. Technol. 2007, 41, 8099-8103.

15. Collins, K.A.; Hunt, W.F.; Hathaway, J.M. Hydrologic comparison of four types of permeable pavement and standard asphalt in eastern North Carolina. J. Hydrol. Eng. 2008, 13, 1146-1157.

16. ASCE. Permeable Pavements: Recommended Design Guidelines; Permeable Pavement Technical Committee of the Water Resources Institute of the American Society of Civil Engineers: Reston, VA, USA, 2013.

17. Drake, J.; Bradford, A.; Seters, T.V. Stormwater quality of spring-summer-fall effluent from three partial-infiltration permeable pavement systems and conventional asphalt pavement. J. Environ. Manag. 2014, 139, 69-79.

18. McDaniel, R.S.; Thornton, W.D.; Dominguez, J.G. Field Evaluation of Porous Asphalt Pavement; Final Report; North Central Superpave Center Purdue University: West Lafayette, IN, USA, 2004.

19. Putman, B.J. Evaluation of Open-Graded Friction Courses: Construction, Maintenance, and Performance; Report No. FHWA-SC-12-04; South Carolina Department of Transportation: Columbia, SC, USA, 2012.

20. TNZ. Specification for Porous Asphalt; Transit New Zeland SP/SP11 070704; TNZ: Wellington, New Zeland, 2007.

21. NAPA. Porous asphalt pavements for stormwater management. In Design, Construction and Maintenance Guide; National Asphalt Pavement Association: Lanham, MD, USA, 2008.

22. Dierkes, C.; Kuhlman, L.; Kandasamy, J.; Angelis, G. Pollution retention capability and maintenance of permeable pavements. In Proceedings of the 9th International Conference on Urban Drainage, Portland, OR, USA, 8-13 September 2002.

23. Agarwal, S.K. Heavy Metal Pollution; A.P.H. Publishing: New Delhi, India, 2009; ISBN 978-81-313-0484-6.

24. Llopart-Mascaró, A.; Ruiz, R.; Martínez, M.; Malgrat, P.; Rubio, P. Analysis of Rainwater quality: Towards sustainable Rainwater management in urban environments. In Proceedings of the Novatech 2010-7th International Conference on Sustainable Techniques and Strategies for Urban Water Management, Lyon, France, 27 June-1 July 2010.

25. WSDOT. Untreated Highway Runoff in Western Washington; Washington State Department of Transportation, Herrera Environmental Consultants, Inc.: Seattle, WA, USA, 2007.

26. Barrett, M.E.; Malina, J.F., Jr.; Charbeneau, R.J.; Ward, G.H. Characterization of Highway Runoff in the Austin Texas Area; Center for Research in Water Resources, Bureau of Engineering Research: Austin, TX, USA, 1995.

27. Yuen, J.; Olin, P.H.; Lim, H.S.; Benner, S.G.; Sutherland, R.A.; Ziegler, A.D. Accumulation of potentially toxic elements in road deposited sediments in residential and light industrial neighborhoods of Singapore. J. Environ. Manag. 2012, 101, 151-163.

28. NRMCA. Freeze-Thaw Resistance of Pervious Concrete; National Ready-Mixed Concrete Association: Silver Spring, MD, USA, 2004.

29. Balades, J.D.; Legret, M.; Madiec, H. Permeable pavements: Pollution management tools. Water Sci. Technol. 1995, 32, 49-56.

30. Pagotto, C.; Legret, M.; Le Cloirec, P. Comparison of the hydraulic behaviour and the quality of highway runoff water according to the type of pavement. Water Res. 2000, 34, 4446-4454.

31. ANA. Nacional de Águas-Brasil (National Water Agency-Brazil). In Conservação e Reúso da Água em Edificações; Agência Prol Editora Gráfica: São Paulo, SP, Brazil, 2005. (In Portuguese).

32. CONAMA. Conselho Nacional do Meio Ambiente Resolução No. 430, de 13 de maio de 2011. In Condiçõese Padrões de Lançamento de Efluentes; Ministério Nacional do Meio Ambiente, Conselho Nacional do Meio Ambiente: Brasília, DF, Brazil, 2011. (In Portuguese).

33. CONAMA. Conselho Nacional do Meio Ambiente Resolução No. 357, de 18 de março de 2005. Classificação dos Corpos de Água e Diretrizes Ambientais Para Seu Enquadramento; Ministério Nacional do Meio Ambiente, Conselho Nacional do Meio Ambiente: Brasília, DF, Brazil, 2005. (In Portuguese).

34. Brazil. Departamento Nacional de Infraestrutura de Transportes/Instituto de Pesquisas Rodoviárias; Coletânea de Normas; (In Portuguese). 2016. Available online: http://ipr.dnit.gov.br/normas-e-manuais/normas (accessed on 1 July 2017). 
35. ASTM (American Society for Testing and Materials). Annual Book of ASTM Standards; ASTM International: Washington, DC, USA, 2002. Volume 03.02. Available online: https://www.astm.org (accessed on 2 Feb 2017).

36. CALTRANS. California Department of Transportation Open Graded Friction Course Usage Guide; Division of Engineering Services: Sacramento, CA, USA, 2006.

37. DER/SP. Especificação Técnica: Pré-Misturado a Quente; Departamento de Estradas de Rodagem de São Paulo: São Paulo, Brazil, 2006. (In Portuguese).

38. UNHSC. Design Specifications for Porous Asphalt Pavement and Infiltrations Beds; University of New Hampshire-Stormwater Center (UNHSC): Durham, NH, USA, 2009.

39. Tota-Maharaj, K.; Scholz, M. Efficiency of permeable pavement systems for the removal of urban runoff pollutants under varying environmental conditions. Environ. Prog. Sustain. Enery 2010, 29, 358-369.

40. Bean, E.Z.; Hunt, W.F.; Bidelshap, D.A. Evaluation of four permeable pavement sites in eastern North Carolina for runoff reduction and water quality impacts. J. Irrig. Drain. Eng. 2007, 133, 583-592.

41. CETESB. Companhia Ambiental do Estado de São Paulo; Publicações e Relatórios: São Paulo, SP, Brazil, 2014. (In Portuguese).

42. LACEN. Manual de Orientação Para Coleta de Água e Amostras Ambientais; Laboratório Central de Saúde Pública: Santa Catarina, Brazil, 2000. (In Portuguese).

43. Quevedo, C.M.G. Avaliação da Presença de Fósforo Nos Esgotos Sanitários e da Atual Contribuição Dos Detergentes. Ph.D. Thesis, Universidade de São Paulo (USP), Faculdade de Saúde Pública, São Paulo, SP, Brazil, 2015. (In Portuguese), doi:10.11606/T.6.2015.tse-07042015-103919.

44. Brow, R.A.; Borst, M. Nutrient infiltration concentration from three permeable pavement types. J. Environ. Manag. 2015, 164, 74-85.

45. Chughtai, M.; Mustafa, S.; Mumtaz, M. Study of physicochemical parameters of rainwater: A case study of Karachi, Pakistan. Am. J. Anal. Chem. 2014, 5, 235-242.

46. Cederkvist, K.; Jensen, M.B.; Holm, P.E. Method for assessment of stormwater treatment facilities-Synhetic road runoff addition including micro-pollutants and tracer. J. Environ. Manag. 2017, 198, 107-117.

(C) 2018 by the authors; Licensee MDPI, Basel, Switzerland. This article is an open access article distributed under the terms and conditions of the Creative Commons Attribution (CC BY) license (http://creativecommons.org/licenses/by/4.0/). 